Int. J. Dev. Biol. 57: 225-239 (2013)

doi: $10.1387 / \mathrm{ijdb} .130042 \mathrm{jd}$

\title{
Endocrine disruptors, gene deregulation and male germ cell tumors
}

\author{
JESÚS DEL MAZO*,1, MIGUEL A. BRIEÑO-ENRÍQUEZZ,1, JESÚS GARCÍA-LÓPEZZ,1, \\ LUIS A. LÓPEZ-FERNÁNDEZ ${ }^{2}$ and MASSIMO DE FELICl ${ }^{3}$ \\ ${ }^{1}$ Department of Cellular and Molecular Biology. Centro de Investigaciones Biológicas (CSIC), Madrid, Spain, \\ ${ }^{2}$ Hospital General Universitario Gregorio Marañón, Madrid, Spain and \\ ${ }^{3}$ Department of Biomedicine and Prevention, University of Rome "Tor Vergata", Rome, Italy
}

\begin{abstract}
Endocrine disruptors (EDs) belong to a large group of compounds, usually present as environmental pollutants, which can alter the homeostasis of living organisms by modifying hormonal balance and changing the normal patterns of gene regulation during development and cell differentiation. Hence, the development of male gonads and their functionality may be affected by exposure to specific EDs or their mixtures. The molecular mechanisms of action of these reprotoxicants leading to pathologies of the reproductive system such as testicular cancer, are complex and not well characterized. It is likely, however, that these compounds alter the interaction between the mechanisms of gene regulation and functional gene networks in windows of risk, mainly during embryonic development. Moreover, such changes could be transmitted through generations by epigenetic mechanisms. There are examples of the action of EDs on the expression of mRNAs, small non-coding RNAs and epigenetic marks in the developing testis associated with cellular and molecular alterations found in germ cell tumors. In the present review, we will discuss various aspects of genetic, transcriptomic and epigenetic changes related to testicular development, exposure to EDs and the occurrence of germ cell tumors.
\end{abstract}

KEY WORDS: testis, tumor, primordial germ cell, miRNA, piRNA, epigenetic, DNA methylation, histone modification

\section{Introduction}

Testis development involves a series of processes of differentiation from early embryogenesis, mainly based in mammals on genetic determinants of male on chromosome Y. Mechanisms of germ and Sertoli cell differentiation, lead to the formation of seminiferous tubules that along with the intertubular Leydig cells form the cellular network of spermatogenesis. Autocrine, paracrine and endocrine regulations and precise specific gene expression allow setting the appearance of male characters and the continuous production of sperm in adult life (Brennan and Capel, 2004; Park and Jameson, 2005).

Spermatogenesis involves complex processes of proliferation, differentiation, cell interactions and morphogenetic changes to produce highly differentiated and haploid cells such as in spermatozoa. Although the time course of cell differentiation can be very variable among different mammals, basic traits of spermatogenesis at the cellular and molecular levels, as well as the developmental progression are comparable; this enables predictions using animal models of study. The exclusive nature of some of these processes requires developmentally orchestrated control of gene expression. It has been estimated that about $4 \%$ of the mouse genome, representing above 2300 genes, is specifically expressed in testis (Schultz et al., 2003). In addition, alternative forms of post-transcriptional

\footnotetext{
Abbreviations used in this paper: BPA, bisphenol A; CIS, carcinoma in situ; DEHP di-(2ethylhexyl) phthalate; dpc, days post coitum; E2, 17beta-estradiol; EC, embryonal carcinoma; EG, embryonal germ; ED, endocrine disruptor; ES, embryonal stem; HR, hormone receptor; MEHP, mono-(2-ethylhexyl) phthalate; miRNA, microRNA; NSGCT, non-seminoma germ cell tumor; PCB, polychlorinated biphenyl; PGC, primordial germ cell; piRNA, piwi-interacting RNA; POP, persistent organochlorine pesticide; SSC, spermatogonial stem cell; TDS, testicular dysgenesis syndrome; TE, transposable elements; TGCT, testicular germ cell tumor; UTR untranslated region; ZEA, zearalenone.
}

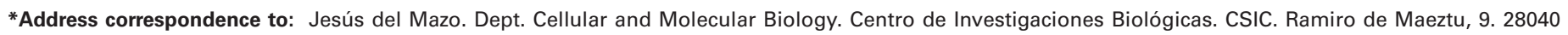
Madrid. Spain. Tel: +34.91.837.3112 ext. 4324. e-mail: jdelmazo@ cib.csic.es

\#Note: Equivalent contribution.

Final, author-corrected PDF published online: 5 June 2013.

ISSN: Online 1696-3547, Print 0214-6282 
regulation of gene expression such as alternative splicing (Yeo et al., 2004), different polyadenilation sites and thus 3'-UTRs (Parraga and del Mazo, 2000; Wang et al., 2006), and differences in the length of poly(A) tails of mRNAs (de Luis and del Mazo, 1998), are frequent in testicular germ cell differentiation.

The recent developments in the "world of small RNAs" are causing a revolution in our knowledge of gene regulation. RNA interference mediated by small non-coding RNAs is a powerful mechanism in the control of gene expression associated with cell differentiation and pathologies. In germ cells, three types of endogenous small RNAs, microRNAs (miRNAs), piwi-interacting RNAs (piRNAs) (initially considered specific of germ cells) and endogenous small interfering RNAs (endo-siRNAs), with cell-type regulated biogenesis (Gonzalez-Gonzalez et al., 2008; GarciaLopez and del Mazo, 2012), are being studied to determine their role in the differentiation of germ cells and its pathologies, including infertility and testicular cancers (He et al., 2009).

The cells and biological systems can be affected by environmental contaminants through alterations of genetic systems, by multiple mechanisms of action also interacting with the genetic backgrounds (Edwards and Myers, 2007). The adverse effect of environmental pollutants on reproductive health is well documented (Woodruff et al., 2008). An important and extensive group of chemical contaminants, widespread in the environment, is called endocrine disruptors (EDs). These are wide groups of chemical compounds such as: pesticides and herbicides, organic compounds, pharmacological substances, heavy metals, persistent organic pollutants, air contaminants that interfere with endocrine pathways and can induce gene deregulation in exposed organisms. To date, hundreds of compounds considered EDs and thousands of others are suspected of having similar properties have been identified. The testis has been clearly identified as a significant target for the deleterious action of these environmental toxicants. This knowledge generates worldwide concern as to consequences for reproductive health both in humans and wild species (Colborn and Clement, 1992). The causal relationship between endocrine disruption by environmental chemicals and disorders such as cancer and infertility has been the subject of numerous scientific reports. A classical, albeit contested, report (Toppari et al., 1996) reached the conclusion that there has been a general, although not necessarily global decline in semen quality during the last fifty years as was previously reported (Carlsen et al., 1992). The report also showed that $2-4 \%$ of the annual increase in testicular cancer was diagnosed in men under 50 years old in Britain, Scandinavia, Australia and the USA. Epidemiological and experimental data indicate that developmental exposure to EDs could induce, at the level of male gonad development and reproduction, the so-called "Testicular Dysgenesis Syndrome" (TDS) (Sharpe and Skakkebaek, 1993; Skakkebaek et al., 2001). TDS includes four clinical and etiologically related traits: hypospadias, cryptorchidism, low sperm counts and testicular tumors (Asklund et al., 2004). The impact of EDs, however, is still unclear due to the wide range of possible mechanisms for ED action, levels of ED exposure, mixture of chemicals potentially acting as EDs and the genetic sensibility of individuals or populations to the compounds.

The effects in germ cells not only may affect the exposed individual but can also be inherited and potentially influence the phenotype of subsequent generations by epigenetic mechanisms. The term "epigenetic", introduced by C.H. Waddington (1905-75) to describe interactions of genes with their environment (Waddington, 1942 ), is now used to define heritable changes in gene expression that are not coded in the DNA sequence. Main epigenetic mechanisms include DNA methylation and histone modifications (Kim et al., 2009). More recently, additional mechanisms have been identified, among them microRNAs (miRNAs) can act on the epigenetic machinery, and in turn miRNA expression can also be controlled by epigenetic mechanisms (Sato et al., 2011). The epigenetic patterns can be transmitted to the daughter cell, and possibly also through generations. In turn, deregulation of miRNAs can affect the regulation of expression of mRNA targets, generating complex mechanisms of alterations with pathological consequences in testis development and function.

\section{Developmental origin of testicular germ cell tumors}

Testicular germ cell tumors (TGCTs) are the most common solid cancers in men aged 15-40 years in developed countries (Huyghe et al., 2003; Hussain et al., 2008), constituting $2 \%$ of all human malignancies (Richiardi et al., 2004; Motzer et al., 2012) and representing the most frequent cause of death as a consequence of solid tumors in this age group (Oosterhuis and Looijenga, 2005). Germ cell tumors represent about $95 \%$ of malignant tumors arising in the testes whereas only $1-5 \%$ of the testicular cancers have their origin on somatic components of the testis: Sertoli and Leydig cells (Mostofi, 1973; Giglio et al., 2003). During the last five decades the prevalence of these tumors increased 2-3 times and each year about 9,000 new cases of TGCTs are diagnosed in USA (Siegel et al., 2012).

TGCTs consist of a heterogeneous group of neoplasms, established at different anatomical locations in the testis. Simplistically, TGCTs can be classified in seminomas (SGCTs) and non-seminomas (NSGCTs). Seminomas have features of the primordial germ cells (PGCs) or gonocytes, the ancestors of spermatogonia while non-seminomas include mixed germ cell tumors (the most common), embryonal carcinoma, teratoma, choriocarcinoma, and yolk sac tumors.

The fetal origin of some types of TGCTs is widely supported (Rajpert-De Meyts et al., 1998; Looijenga et al., 2007b; Kristensen et al., 2008; Wohlfahrt-Veje et al., 2009). Due to their physiological and genetic similarities, PGCs are considered the cell origin of the TGCTs (Rajpert-De Meyts, 2006). Indeed, seminomas have clear features of PGCs (see below) (Jiang and Nadeau, 2001; Oosterhuis and Looijenga, 2005; Gilbert et al., 2011). Both seminomas and teratocarcinomas derived from abnormal germ cells that initiate within the seminiferous epithelium as carcinoma in situ(Skakkebaek, 1972). Carcinoma in situ and embryonic stem cell display similar profiles of gene expression (Almstrup et al., 2004).

Although controversial (Vidaeff and Sever, 2005), epidemiological studies in humans associate the exposure to different environmental toxicants with the development of TGCTs. Epidemiological studies support the hypothesis that testicular cancer is associated with exposure to some EDs, at least to estrogens (Storgaard et al., 2006), during the fetal or early postnatal life. Exposures to persistent organochlorine pesticides (POPs) have been associated to risk increase of seminomas and non-seminomas testicular cancers (McGlynn et al., 2008). However, no association with exposure to polychlorinated biphenyls (PCBs) (even, inverted association) was detected (McGlynn et al., 2009), speculatively explained by the 
wide range of effects of the different PCBs and mixes (estrogenic, antiestrogenic, androgenic, and antiandrogenic).

The Sertoli cells as somatic components of the seminiferous epithelium play a pivotal role in the development of a functional testis, and as consequence in the development of the male phenotype (Skinner and Griswold, 2005). Their direct interaction with male germ cells into the seminiferous epithelium is crucial during spermatogenesis. Disorders in the correct maturation or numbers of Sertoli cells thus may be the cause of male reproductive disorders (reviewed by Sharpe et al., 2003). Similarly, the Leydig cell represents a crucial element of testis functions, basically through the secretion of androgens (Payne et al., 1996). The effects of EDs on such cells are considered of special relevance due to hormonal regulation of Sertoli and Leydig cells functions and by the hypothesis that the TDS could be mainly caused by functional disorders in Sertoli and Leydig cells (Sharpe et al., 2003). However, dysregulation of gene expression in these cell types as consequence of ED exposures seems to cause dysfunctions in traits of TDS other than testicular cancer. Therefore, Sertoli or Leydig cells tumors will not be discussed in this review.

\section{Genetic background of testicular germ cell tumors}

From the genetic point of view, chromosomal unbalance is usually found in diverse forms of TGCT. The most common cytogenetic alteration is the amplification of human chromosome $12 p$ region (Looijenga et al., 2003b; Rodriguez et al., 2003; Zafarana et al., 2003; von Eyben, 2004). Different TGCTs show particular chromosome abnormality pattern. While in non-seminoma germ cell tumors gain of proximal $17 q$ and loss of $10 q$ have been usually detected (Mohamed et al., 2012), seminomas show high-level amplification of 12p (Zafarana et al., 2003; Mohamed et al., 2012). Interestingly, this chromosome region contains multiple genes postulated to be involved in TGCT, such as CCND2, STELLAR and NANOG, expressing in PGCs and playing important roles in stem cell maintenance (Houldsworth et al., 2006).

Compared to chromosomal abnormalities, specific gene mutations in TGCT are less frequent. The most frequent single genes affected in TGCTs are: KIT, TP53, K-RAS, N-RAS, and $B-R A F$ (reviewed bySheikine et al., 2012). Genetic susceptibility to TGCTs conditioning the familial testicular germ cell tumors has been established, confirming mutations or single nucleotide polymorphisms (SNPs) affecting some genes involved in the normal germ cell differentiation such as KITLG, SPRY4, PDE11A and BAK1 (Greene et al., 2010).

Genetic susceptibility to TGCTs by exposure to some types of EDs is currently being studied more intensively. Genetic polymorphism in humans, such as those found on hormone-metabolizing genes including CYP17A1 and HSD17B1, can also modified the association between TGCT risk and exposure to specific EDs such as POPs (Chia et al., 2010). The combination of genotyping and transcriptome analysis (named genetical genomics) could differentiate the genetic from the environmental components of gene expression variations (Gibson, 2008). After genome-wide association (GWA) studies, new approaches based on gene-environment (G×E) interactions methodology (Thomas, 2010; van ljzendoorn et al., 2011) will probably contribute to clarify the complex pathways involving multiple genes and exposures.

\section{Comparing gene expression in PGCs and testicular germ cell neoplasias}

In mammals, PGCs are the embryonic precursors of both female and male germ cells (De Felici, 2001). As we are going to discuss below, in the mouse embryo, PGCs are determined in the extraembryonic mesoderm of the yolk sac wall around the gastrulation period ( 6.5 days post coitum, dpc; and around the third week of gestation in humans) (McLaren, 2003; Saitou et al., 2003; De Felici, 2012). From this region, they migrate within the developing gonadal ridges where they differentiate into female or male germ cells. Within the fetal testis, PGCs after a proliferation period exit temporarily from the cell cycle and are arrested in G0. Such quiescent cells included inside seminiferous cords are now called prespermatogonia or gonocytes. The sexual dimorphism of the mouse gonads is evident at 12.5-13.5 dpc (Fig. 1). Spermatogonial stem cells (SSCs) of the newborn and prepuberal testis derive from gonocytes although the processes of their differentiation from these cells are unknown. SSCs can self-renew and generate a large number of differentiated germ cells. In particular, they give rise to type A spermatogonia which after some rounds of proliferation differentiate into type B spermatogonia; these latter entering into meiosis become spermatocytes. After meiotic divisions, haploid spermatids are produced, suffering morphogenetic changes until their subsequent differentiation into spermatozoa.

The transcriptional repressor BLIMP1 (B-lymphocyte-induced maturation protein 1) participates in the initial specification of PGCs repressing their somatic program (Saitou et al., 2003; McLaren and Lawson, 2005; Ohinata et al., 2005; Vincent et al., 2005). Subsequently, PGCs move from the proximal epiblast to the extraembryonic mesoderm of the yolk sac wall and then through the hindgut and dorsal mesentery to the gonadal ridges $(11.5 \mathrm{dpc}$ in mice and the 6th week in humans) (Godin et al., 1991; Wylie, 1993; Donovan, 1994; Runyan et al., 2006; Sheikine et al., 2012).
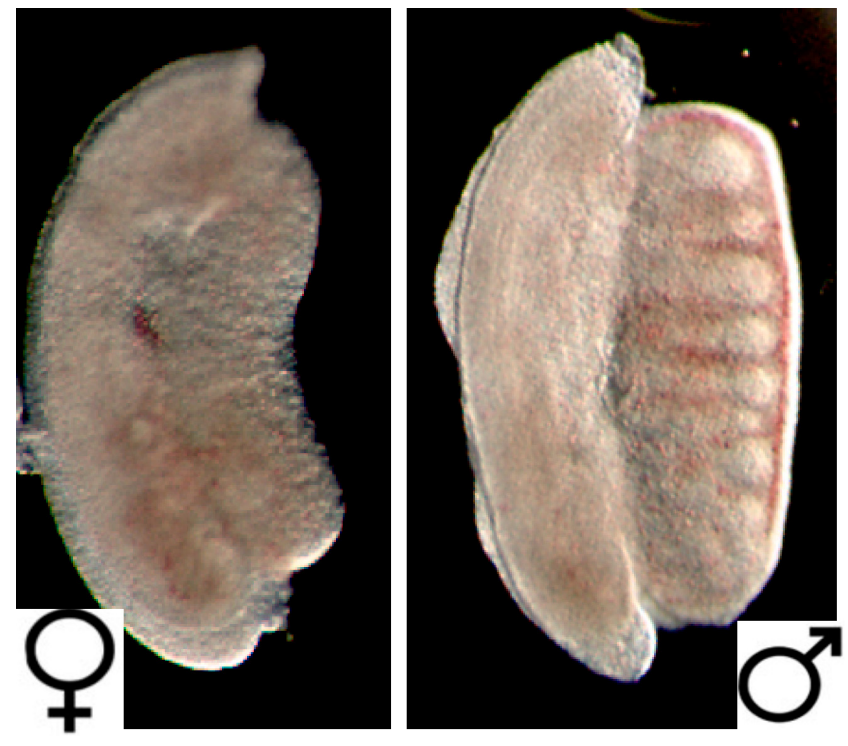

Fig. 1. In mice, the sexual dimorphism of the fetal gonads is clearly evident at $\mathbf{1 3 . 5} \mathbf{d p c}$. The mesonephros, with an important role in sexual differentiation, is associated with the left of each gonad. 
During this period, PGC development is regulated by a variety of growth factors and cytokines including BMPs (bone morphogenic proteins), Kit ligand (KITLG), also known as the stem cell factor (SCF), and SDF1 (stromal cell derived-1) (for a review, see (De Felici and Farini, 2012). PGCs and gonocytes express several markers typical of stem cells such as TNAP (tissue not specific alkaline phosphatase), NANOG, ESG1, SOX2, POU5F1 (also known as OCT3/4), and SALL4 (Saitou et al., 2002; Saitou et al., 2003; Gashaw et al., 2007; Niwa, 2007), as well as germ cell specific such as MVH, NOBOX, DAZL, NANOS3 (reviewed by De Felici, 2009). PGCs and in part gonocytes have their original genomic imprinting pattern erased, which allows development of genderspecific germ cell lineages. PGCs maintain intrinsic pluripotency up to their differentiation into oocytes and gonocytes as shown by their capability to produce teratomas/teratocarcinoma or embryonal germ (EG) cells (for a review, see(Donovan and de Miguel, 2003).

It is likely that at least in part PGC intrinsic pluripotency depends on the methylation status of imprinted genes such as H19, IGF2, IGF2R and SNRPM (Szabo and Mann, 1995). The loss of imprinting in PGCs could be considered as one of the pathways implied in their differentiation and loss of pluripotency. In the presence of the $\mathrm{Y}$ chromosome, the gonadal stromal cells of the gonadal ridges express the transcription factor SRY and its target gene SOX9driving Sertoli cell differentiation (Polanco and Koopman, 2007). The Sertoli cells create a microenvironment that allows differentiation of gonocytes into SSCs. During the differentiation process, germ cells gradually lose expression of NANOG, PLAP, and POU5F1, partially of $K I T$ and $S A L L 4$, and acquire expression of other genes including MAGE4A, and TSPY (Cao et al., 2009). Gene signature of deregulation in TGCTs respect to normal male germ cells has been reported based on array analysis in different histological entities of TGCTs (Okada et al., 2003; Gashaw et al., 2005). These studies have associated patterns of deregulation of specific genes as potential molecular markers of gene expression that define types of TGCTs and prognosis of such tumors (Gashaw et al., 2005). One feature that could define the fetal origin of TGCTs is the similarity of the patterns of gene expression between PGCs/gonocytes and neoplasic cells of testicular tumors (Almstrup et al., 2004). Analysis by cDNA microarrays defined expression profile of 895 genes that were upregulated in human embryonal stem (ES) cells and carcinoma lines respect to the controls, showing highest expression the OCT3/4 gene and confirming the hypothesis that human seminomas most closely resemble transformed PGCs (Sperger et al., 2003). Interestingly, high representations of deregulated genes are localized on the $12 p$ chromosome region.

In humans, seminomas, embryonal carcinoma, carcinoma in situ (CIS) and yolk sac tumors show expression of OCT3/4 (Palumbo et al., 2002; Looijenga et al., 2003a; de Jong et al., 2005; Richie, 2005; Jung et al., 2006), NANOG (Hart et al., 2005; Hoei-Hansen et al., 2005) and LIN28 (West et al., 2009; Gillis et al., 2011) which are not detectable in either normal testicular tissue or in teratomas. During development of human germ cell, the genes OCT3/4, NANOG and LIN28 are expressed in PGCs and gonocytes being LIN28 extended to prespermatogonia (Yeom et al., 1996; Brehm et al., 1998; Gillis et al., 2011), amongst others involved in pluripotency (Nichols et al., 1998). In mouse, LIN28 regulates the expression of members of the family of miRNA: miR-let-7 (Hagan et al., 2009), which potentially regulates other multiple potential mRNA targets. The regulation of specific gene expression during early development is also medi- ated by DNA methylation as occurs in the expression of OCT3/4 (Gidekel and Bergman, 2002) whose expression levels appear a crucial key in the neoplasic process (Gidekel et al., 2003). Other functional markers of gene expression in TGCTs common to early differentiated germ cells and CIS, are PLAP (Hustin et al., 1987) and $c-K I T$ (Rajpert-De Meyts and Skakkebaek, 1994; Strohmeyer et al., 1995; Honecker et al., 2004; Motzer et al., 2012).

In contrast to other cancers, there are few animal models of TGCTs. In mouse, the only strain that developed TGCTs, and which also proved to originate from PGCs is the 129/SvJ strain, discovered by more than 50 years ago by Stevens (Stevens and Little, 1954; Stevens and Hummel, 1957; Stevens, 1962; Stevens, 1964; Stevens, 1967; Stevens, 1973; Stevens, 1984). More recently, it has identified mutations in the mouse homologous gene of zebrafish (Weidinger et al., 2003): dead end homolog 1 (Dnd1) gene as an inducer of this phenotype (Matin and Nadeau, 2005; Youngren et al., 2005). Dnd1 encodes a protein participating in the "editosome" with activity of RNA-binding protein (Youngren et al., 2005). RNA editing is a post transcriptional key regulator of gene expression (Keegan et al., 2001) that generate alternative RNAs including mRNAs and double stranded RNAs such as are the miRNAs precursors (Nishikura, 2010). Recently, it has been reported the binding of Dnd1 to transcripts encoding negative regulators of the cell-cycle, involved in developing male germ cell mitotic arrest (Western et al., 2008), such as: p21Cip1, p27Kip1, Lats2, pRB, p53 and Pten promoting translation regulation (Cook et al., 2011) as was previously suggested (Western, 2009). Experimental deletion of Pten in PGCs drives to testicular teratomas and abnormal germ cell proliferation (Kimura et al., 2003; Moe-Behrens et al., 2003). It has been proposed that a regulatory mechanism of Dnd1 is based on the protection of specific transcripts, as those mentioned, to the negative post-transcriptional regulation of miRNAs. In this view, the binding of the transcripts to 3' UTR regions protects for the binding and activity of miRNA competing for the same mRNA regions, as was observed in zebrafish where Dnd1 protein is able to protect Nanos from the negative translation regulatory action of miR-430 during PGC development (Kedde et al., 2007). Combining both potential activities of Dnd1, a dual action of Dnd1 can be hypothesized: modification the sequence of miRNAs in their biogenesis and therefore divert them from their initial target, or alternatively competition with the target miRNAs. Consequently, complex regulatory mechanisms at postranscriptional level could also be involved in the genetic program of germ cells development in the embryo being their unbalance involved in testicular tumorogenesis.

\section{Effects of endocrine disruptors on gene expression in PGCs and developing testis}

Studies of transcriptome changes in testicular cells after chemical exposure have been carried out in mouse models using both in vitro and in vivo approaches. In vitro analysis allows to define changes of gene expression in specific cell types. Yet, the in vitro approaches create a handicap due to the removal in isolating cells from their natural physiological conditions. This method also is valid for cell types present in the precise time frame during testis development such as PGCs. For example, the level of AKT kinase activity, that is induce by phosphorylation of the KIT-ligand, crucial for PGC survival/proliferation, significantly decreased in mouse $\mathrm{PGCs}$ exposed to lindane (gamma- $\mathrm{HCH}$ ) in vitro along with the 
TABLE 1

\section{GENES DEREGULATED IN PGCS AFTER IN VITRO EXPOSURE TO DIFFERENT TOXICANTS}

\begin{tabular}{cclc} 
Compound & Gene Symbol & Gene Name & Regulation \\
\hline MEPH & $R p l 8$ & ribosomal protein L8 & UP \\
MEPH & $R p l 24$ & ribosomal protein L24 & UP \\
MEPH & $m t-N d 1$ & ND1 NADH dehydrogenase subunit 1 & DOWN \\
MEPH & $R p l 10 a$ & ribosomal protein L10A & DOWN \\
MEPH & Eif2s2 & $\begin{array}{l}\text { Eukaryotic translation initiation factor 2, subunit 2 } \\
\text { (beta) }\end{array}$ & DOWN \\
MEPH & Fau & Finkel-Biskis-Reilly murine sarcoma virus (FBR- & DOWN \\
& & MuSV) ubiquitously expressed (fox derived) & \\
MEPH & $m t-C o 3$ & Cytochrome Oxidase III, COX3 & DOWN \\
ENU & $R p l p 1$ & Ribosomal protein, large, P1 & UP \\
ENU & $R p / 31$ & ribosomal protein L31 & UP \\
ENU & $R p l 28$ & ribosomal protein L28 & UP \\
ENU & $R p l 35$ & ribosomal protein L35 & UP \\
ENU & $R p s 17$ & ribosomal protein S17 & UP \\
ENU & $m t-C o 3$ & Cytochrome Oxidase III, COX3 & DOWN \\
ENU & $R p s 8$ & ribosomal protein S8 & DOWN \\
ENU & $m t-C o 1$ & cytochrome c oxidase subunit I & DOWN \\
ENU & $m t-N d 2$ & NADH dehydrogenase subunit 2, mitochondrial & DOWN \\
ENU & Sod1 & superoxide dismutase 1, soluble & DOWN \\
ADR & Hbb-Y & hemoglobin Y, beta-like embryonic chain & UP \\
ADR & $R p l 41$ & ribosomal protein L41 & DOWN \\
\hline
\end{tabular}

Deregulated genes were identified by differential screening of gene expression from cDNA libraries MEHP (mono-2-ethylhexyl phthalate), ADR (adriamycin) ENU (N-ethyl-N-nitrosourea)

increase in the number of apoptotic PGCs induced by lindane either in culture and in the embryo (La Sala et al., 2009). Moreover, in a similar in vitro assay 17-beta-estradiol (E2) was able to rapid stimulation of AKT, KIT ERK2 and SRC phosphorylation in mouse PGCs (La Sala et al., 2010).

Others in vitro studies have shown differential response of PGCs to toxicants with different mechanisms of action. In vitro cultured PGCs exposed to N-ethyl-N-nitrosourea (ENU) (a classical toxicant and mutagen, with effects on spermatogenic cells) (Lessard et al., 2004) or Doxorubicin (trade nameAdramycin, ADR) an anthracycline widely used in cancer therapy, with apoptotic effects on spermatogenic cells (Sjoblom et al., 1998) demonstrated growth inhibition and apoptosis induction, whereas exposure to mono (2-ethylhexyl) phthalate (MEHP) (the direct metabolite of the di (2-ethylhexyl) phthalate or DEHP), a widespread plasticizer, ubiquitously found as environmental pollutant affected PGC adhesion to cell monolayers (lona et al., 2002).

In order to identify gene deregulation as early response to different toxicants cDNA libraries prepared from limited amount of cells followed by differential screening showed highly altered gene expression in PGCs after exposure in vitro to EDs (Table 1) (our own data). Most of deregulated genes detected encode proteins involved in pathways basic for cell survival: respiratory chain and oxidative stress, ribosomal proteins, metabolism of the cell and translation factors. The relationship between mitochondrial reactive oxygen species (ROS) and survival/cell death is well established (Orrenius, 2007) and was classically related to fertility impairment (Sikka et al., 1995). The survival of mammalian cells exposed to adverse environmental conditions requires a radical reprogramming of protein translation (Yamasaki and Anderson, 2008).

Studies of gene expression deregulation caused by environmen- tal reprotoxicant exposure on testis, including EDs, have focused on the analysis of specific genes and defined genetic pathways (Richburg et al., 2002; Edwards and Myers, 2007). The use of DNA microarray technology has implemented the understanding of the molecular basis of the effects EDs and other toxicants (Francois et al., 2003; Iguchi et al., 2006; Iguchi et al., 2007). Vinclozolin is a known ED, used as fungicide, with antiandrogenic activity (Kelce et al., 1994). Analysis by microarrays of changes in the transcriptome of embryo testes from rats exposed during embryonic period to vinclozolin showed altered expression of 576 genes in embryo at 13-16 dpc (Clement et al., 2010). Gene expression deregulation can be based on epigenetic mechanisms as was reported by the same research team (Anway et al., 2005; Anway et al., 2006). Some of the deregulated genes are close related with cancer development such as the tumor suppressor HIC2 (hypermethylated in cancer 2).

Recently, we also reported a comparative analysis of the effect of different EDs on gene expression in developing testis, assessing at the same time dosage and developmental periods of exposure (Lopez-Casas et al., 2012). Five compounds of different nature, but all considered as ED, were analyzed. 17beta-estradiol (E2), as a natural estrogen; lindane, as one of the oldest synthetic pesticides still in use worldwide; mono-(2-ethylhexyl) phthalate (MEHP), bisphenol A (BPA) as a worldwide environmental contaminant and zearalenone (ZEA) a non steroidal estrogenic mycotoxin. Experimental deleterious effects of each of these compounds have been widely reported. The experimental plan included in vivo exposure of mice to several doses of EDs following a defined protocol: mothers were exposed two weeks before mating; the same exposure and dose were maintained during pregnancy and four weeks after birth. The results indicated that the different EDs act during testis development and germ cell differentiation with different mechanisms and diverse molecular pathways, as shown by their patterns of gene expression deregulation. MEHP and ZEA exposures define specific gene expression signatures after unsupervised hierarchical clustering analysis of 2670 genes. The pattern of deregulation was irrespective of the concentration of the toxicant or the developmental period during which exposure occurred, which strongly suggested that the mechanisms of action at the level of deregulation of gene expression occurred in the early stages of development, since in an experimental group of mice the exposure period was only for two weeks in pre-matting mothers. Maternal accumulation of the EDs or epigenetic effects could explain the pattern of altered gene expression in adult testis (Lopez-Casas et al., 2012). Interestingly, the most relevant gene network of the deregulated genes is involved in pathologies affecting: cancer, developmental and endocrine system disorders. In agreement with previous studies of toxicity of 309 chemicals, mostly pesticides, analyzed in ES cells in vitro (Chandler et al., 2011), we detected that genes involved in oxidative stress response pathways such as Nrf2 are highly deregulated by exposure to the different EDs analyzed. Genes involved in testicular embryonal carcinoma progression, including matrix metalloproteinase 2 (Mmp2) have also been recently reported as overexpressed in testicular carcinoma cells exposed to MEHP (Yao et al., 2012).

\section{Epigenetics}

Epigenetics is referred to changes in gene expression transmitted mitotically and meiotically without altering the DNA sequence. Consequently, epigenetic changes are key process both in cell 
differentiation and as result of environmental impact on biological processes (Youngson and Whitelaw, 2008; Feil and Fraga, 2012).

The most relevant epigenetic processes are: methylation of cytosine residues on DNA (Bird and Wolffe, 1999), post-translational modification of histone tails (Jenuwein and Allis, 2001), and regulation by noncoding RNAs (especially miRNAs) (Chuang and Jones, 2007; Costa, 2008). All this epigenetic processes contribute to define the condensed or decondensed chromatin state and consequently gene expression. DNA methylation is the most studied mechanism of epigenetic regulation. Cytosine methylation primarily occurs in CpG dinucleotides in CpG-rich sequences, known as $\mathrm{CpG}$ islands that is often found near or in the gene promoter regions and usually unmethylated in somatic cells but differentially methylated in genes of the germline (Bird et al., 1985; Cross and Bird, 1995; Weber et al., 2007; Borgel et al., 2010; Popp et al., 2010; Hackett et al., 2012). DNA methylation, maintained by DNA methyltransferases, is a crucial mechanism of epigenetic gene silencing of cell-specific genes and transposons, cell differentiation and development, parental genomic imprinting, X chromosome inactivation in mammals and maintenance of cellular pluripotency (De Carvalho et al., 2010; Meissner, 2010; Portela and Esteller, 2010).

The epigenetic reprogramming of PGCs development is necessary to provide these cells pluripotency (De Felici, 2011). Global demethylation of PGCs appears to be a key mechanism in this reprogramming (Popp et al., 2010; Surani and Hajkova, 2010). However, some genes potentially germline determinants, escape the global demethylation, suggesting transgenerational transmission of DNA methylation pattern for these specific genes (Borgel et al., 2010).

Epigenetic alteration, mainly changes in DNA methylation, is a common trait in cancer (Esteller, 2007; Sharma et al., 2010). In TGCTs, the pattern of imprinted genes is similar to that observed in normal embryonic cells, indicating again the embryonic origin of the TGC and the possible role of epigenetic changes in TGCTs in adults (van Gurp et al., 1994; Schneider et al., 2001; Sievers et al., 2005). The analysis of global methylation in TGCTs showed a profile distinct to other types of cancer affecting somatic cells (Ushida et al., 2012), mimicking the pattern obtained in PGCs (Okamoto and Kawakami, 2007). However, differences are also founds between seminomas and non-seminomas. Seminomas show hypomethylation at the $\mathrm{CpG}$ islands while non-seminomas that show $\mathrm{CpG}$ island methylation at a level similar to other solid tumors (Smiraglia et al., 2002), which can be related with the differentiation state of PGCs in the timing of the transformation to tumorogenic cells as has been proposed (Rajpert-De Meyts et al., 1998).

Analyses of methylation levels in specific relevant genes also show alterations in TGCTs. In this sense, the serine protease testisin (PRSS21) expressing in premeiotic testicular cells and considered as tumor suppressor gene is also down-regulated in TGCTs (Kempkensteffen et al., 2006) probably due to the high level of hypermethylation at the promoter region as was detected in TGCTs (Manton et al., 2005).

The fact that methylation patterns, and its alterations can be transmitted transgenerationally encourage the study of specific epigenetic changes in DNA methylation as a result of exposure to toxicants compounds during gonadal development and their potential pathological consequences. Limited studies have been carried out in this respect. MGMT (O6-methylguanine-DNA methyltransferase) is a DNA repair enzyme participating in the natural defence against cytotoxics. Loss of MGMT function can facilitates mutagenesis in oncogenes and tumor suppressors genes (Gerson, 2004). Down-regulation of MGMT due to hypermethylation of its promoter has been associated to different types of cancers, including testicular cancer showing higher hypermethylation levels in non-seminomas respect to seminomas (Smith-Sorensen et al., 2002; Honorio et al., 2003).

Due to the multiple potential mechanisms of action of the EDs, diverse environmental epigenetic inferences have been reported (Zhang and Ho, 2011). Altered patterns of methylation domains of parental imprinted genes were reported in the sperm of mice exposed to the antiandrogen vinclozolin (Stouder and Paoloni-Giacobino, 2010). BPA alters the coat colour in the agouti mice (Dolinoy et al., 2007b), character highly sensitive to changes in methylation (Dolinoy et al., 2007a). BPA also induced in the mouse hypomethylation of the Hoxa10 gene in uterine cells of females exposed in embryonic life (Bromer et al., 2010). Similarly, low dosage of BPA induces in neonatal rats hypomethylation of the phosphodiesterase Pde4d4 promoter (Ho et al., 2006). The exposure of mice to $\mathrm{DEHP}$ results in global increase of genome methylation level in the testis in addition to significantly increase of transcript expression of Dmnt1, Dmnt3a and Dmnt3b methyltransferase genes (Wu et al., 2010) which are essentials for the establishment of cytosine residue methylation (Li et al., 2003). Transgenerational effects of specific ED have been reported. The studies, contested by other reported by the chemical industry (Schneider et al., 2008), based on the effect on epigenetic mechanisms transmitted by germ cells were basically carried out by the exposure to vinclozolin (Anway et al., 2005; Skinner and Anway, 2005; Anway et al., 2006; Skinner, 2007; Skinner et al., 2011). The window of exposure during development is crucial for the phenotypic manifestation in adults and in successive generations. Only exposure in utero, during the period of formation of embryonic germ cells and their DNA methylation changes, affected later in adult germ cells (Cupp et al., 2003; Uzumcu et al., 2004).

Histone methylation is a post-translational modification of these key proteins involved in the dynamic and stability of chromatin conformation, and potentially in gene expression (Greer and Shi, 2012). Recent bioinformatics approach, based on previously reported data of gene expression in testis in different mammals exposed to vinclozolin and dibutyl-phthalate versus unexposed, suggests that histone methylation states, and particularly the regulation of demethylase $K d m 1$, could participate in the phenotypes observed as consequence to EDs exposures and their potential transgenerational epigenetic inheritance (Anderson et al., 2012). Although still incipient, the most studied mechanism concerning histone modification is the histone $\mathrm{H} 3$ lysine 9 trimethylation (H3K9me3) but hundreds of modifications with potential effects on epigenetic modifications should occurs considering all components of the core histones of the chromatin (Kubicek et al., 2006; Bannister and Kouzarides, 2011). Recently, the histone demethylase (H3K27) UTX has been reported as the safeguard of H3K27me3 demethylation observed in PGCs (Sansam et al., 2003). However, histone modifications potentially due to EDs and effects on testis development are rarely reported.

Based in the concept of epigenetic adaptation to exposure to adverse conditions during fetal development (Heijmans et al., 2009; Tobi et al., 2009), it is suggestive to hypothesize that the exposure to a particular ED could modify the epigenetic pattern 
of cells destined to be germ cells, such as PGCs, conditioning an "adaptive" response later for not differentiate, as a "hibernation", in response to the "adverse environment". Such circumstances might condition the maintenance of the undifferentiated state throughout the development and be the niche of carcinoma in situ. In adulthood, these cells "epigenetically misplaced" and under conditions that no longer exists: the environmental element that induced such a change, could enter into proliferative processes and be the source of TGCS.

The lack of an unequivocal cause-effect relationship or "epigenetic gambling" in terms of sensitivity or risk of these events could be due to both the genetic background of individuals and the ability to "adaptive resistance" of some cells from other (Martin, 2009), even in the same genetic background as in monozygotic twins where there are different responses and patterns of DNA methylation (Fraga et al., 2005).

\section{Small non-coding RNAs}

From a biological point of view, the transcriptome and the posttranscriptional regulation is far more complex than originally thought. Small non-coding regulatory RNAs have emerged as pivotal posttranscriptional modulators of gene expression and are involved in diverse processes of cell differentiation and development. In particular, microRNAs (miRNAs) and Piwi-interacting RNAs (piRNAs) are increasingly seen as important elements in both gonadal development and spermatogenesis and their pathologies (Yu et al., 2005; Looijenga et al., 2007a; Ro et al., 2007; Hayashi et al., 2008).

miRNAs are small non-coding RNAs $(\approx 22 \mathrm{nt}$ long) that act as potent modulators of gene expression by targeting 3' UTR regions of mRNAs inducing their cleavage or translational repression (Ambros, 2001; Ross et al., 2007; Guarnieri and DiLeone, 2008; Chua etal., 2009). The majority of miRNAgenes are transcribed from intergenic regions of the genome and the primary transcripts are known as pri-miRNAs ( $\approx 200-100 \mathrm{nt}$ long). These pri-miRNAs are double stranded RNA molecules fold into hairpins, which undergoes two processing steps before to render a mature and functional molecule. In these processing steps are involved two members of the RNase III family of enzymes: DROSHA and DICER. The first processing step occurs in the nucleus, and the product of Drosha cleavage is named pre-miRNA $(\approx 70 \mathrm{nt}$ long). The premicroRNAs are exported to the cytoplasm where DICER processed it, generating a double stranded structure without hairpins, known as miRNA duplex. One or both strands could be incorporated into the miRNA-induced complex (miRISC or simply RISC), whose function is to mediate the translational repression of mRNAs by base-pair complementarity among miRNA and mRNA sequences (Lau and MacRae, 2009; Snead and Rossi, 2010; Ladomery et al., 2011). Thousands of human genes, representing about $30 \%$ of the humangene set, are miRNA targets (Bentwich, 2005;
Bentwich et al., 2005; Lewis et al., 2005); individual miRNAs can suppress the production of hundreds of proteins (Selbach et al., 2008); more than 1000 miRNA have been predicted as well as functional polymorphisms within miRNA-binding sites from mRNAs (Mu and Zhang, 2012). Additionally, the double stranded nature of the primary miRNAs allow potential editing mechanisms (adenosine to inosine) enhancing the diversity of alternative miRNAs from the same precursors and therefore increasing their potential in the post-transcription regulatory modulation of mRNA expression (Blow et al., 2006). Our recent studies suggest differential and active dynamics of miRNA edition and degradation associated to fertilization (García-López et al., 2013).

piRNAs are short RNA molecules (but larger than miRNAs) (24$32 \mathrm{nt}$ long) that are processed in a DICER/DROSHA-independent manner and associated to PIWI proteins (Aravin et al., 2006). They have a role in transposable elements (TEs) silencing (Siomi et al., 2011) and interacting with DNA methylation during spermatogenesis, being basically detected in male germ cells (Aravin et al., 2006; Girard et al., 2006; Grivna et al., 2006; Kim, 2006), although recently they have also been identified in brain cells (Rajasethupathy et al., 2012).

\section{Small non-coding RNAs and TGCTs}

Recent studies reported the alteration of miRNA expression in different cells and tissues induced by diverse environmental pollutants, including some considered EDs (Fig.2) (Izzotti et al., 2009a; Izzotti et al., 2009b; Avissar-Whiting et al., 2010; Hou et al., 2011; Hou et al., 2012). Differential expression of miRNAs in human cancer compared with normal cells showed defined signatures associated to diagnosis, progression and prognosis (Calin and Croce, 2006).

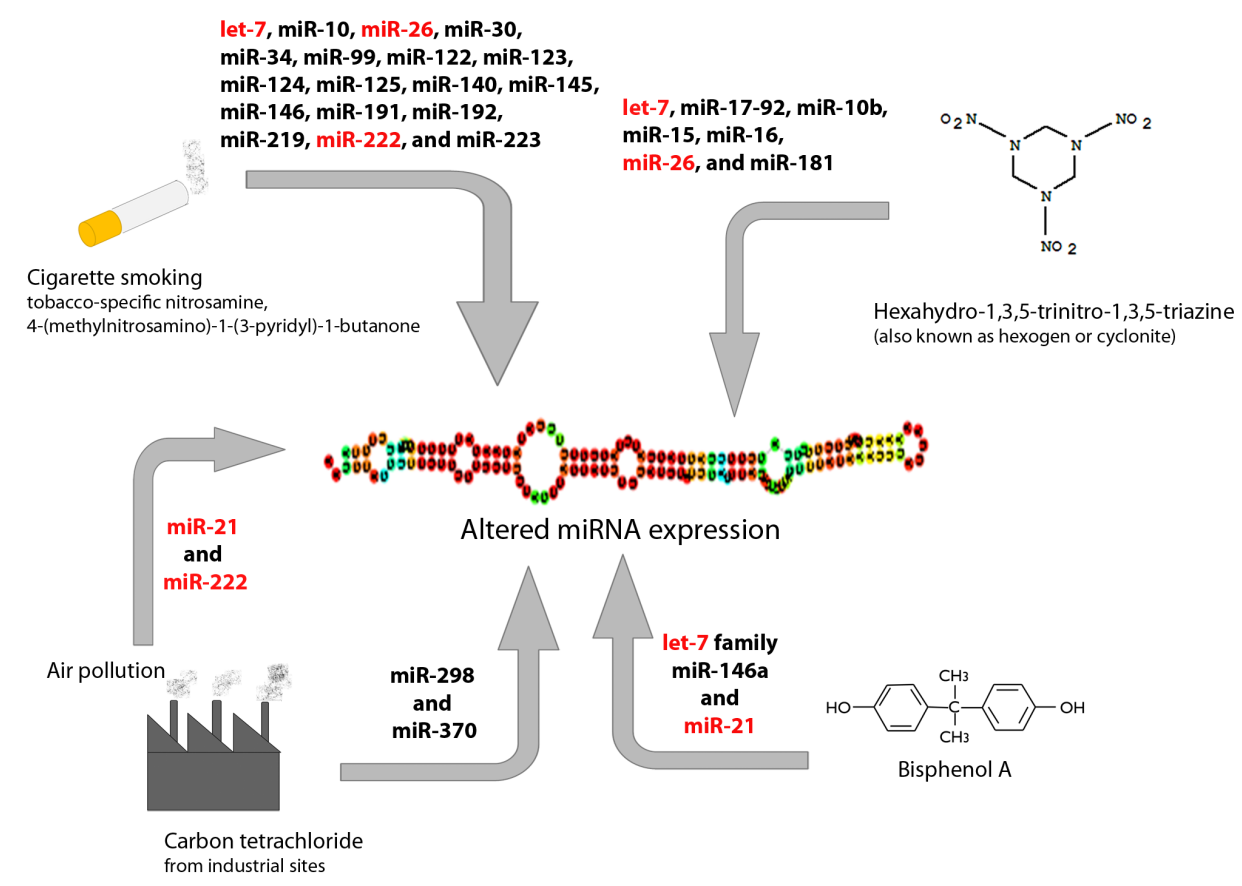

Fig. 2. miRNAs deregulated in different tissues after exposure of various contaminant agents including endocrine disruptors, such as bisphenol A (BPA). The expression of some miRNAs was altered regardless of the inducer chemical agent or environmental factor (in red). 
As mentioned, the origins of testicular germ cell cancer have been associated to dysfunctional gonocytes from fetal development. The expression of PRDM1 (also known as BLIMP1) is essential for PGC commitment (Ohinata et al., 2005). PRDM1 can be modulated by miR-let-7 family of miRNAs. In turn, LIN28 is a miRNA-binding protein that controls the maturation of the precursor of miR-let-7(Heo et al., 2008; Newman et al., 2008; Piskounova et al., 2008; Rybak et al., 2008; Viswanathan et al., 2008; Hagan et al., 2009). Consequently, increased level of let-7 can block the PGGs development. In fact, in vitro knockdown of LIN28 in the mouse reduce the number of PGC colonies (West et al., 2009) and also alters the expression of Prdm14, which is essential for germline specification. Moreover, downregulation of let-7, that is considered as tumor suppressor (Johnson et al., 2005; Lee and Dutta, 2007), and overexpression of $L I N 28$ were linked to tumorogenesis (Chang et al., 2009; Lu et al., 2009). Consequently, the reported association of the overexpression of LIN28 and its homologue LIN28b with human germ cell tumors is consistent (West et al., 2009). Interestingly, the deregulation of LIN28 is only associate to germ cell malignant tumors including seminomas, choriocarcinomas, embryonal carcinomas and yolk-sac tumours, but not to teratomas and normal testis (West et al., 2009).

As in other types of cancer, TGCTs present particular miRNA expression profiles but related with the developmental origin (Mclver et al., 2012). The hsa-miR-302 and the hsa-miR-371 373 clusters are overexpressed in seminomas malignant tumors. However, the expression of miRNAs of these cluster are not altered in teratomas and non-malignant tumors (Palmer etal., 2010). These clusters have been involved in the maintenance of pluripotency and their altered expression profile could be related with the differentiation grade of the tumor. The miRNA expression profile is even different among the types of testicular tumors (Gillis et al., 2007). For example, hsa-miR-21, miR-155, miR-19a and miR-29a are overexpressed in type III tumors and seminomas, while hsa-miR-145, miR-146 and $\mathrm{miR}$-133a are under-expressed in both types of carcinomas in comparison with control samples (Gillis et al., 2007). In general, it has been observed lower expression levels of miRNAs in cancers compared with control samples (Zhang et al., 2007; Pan et al., 2011). The relationship between the miRNA decay and cancer could be explained by the role of miRNA in cell differentiation and cell survival. But not only the miRNA expression decay was related to cancer disease, in other cases the up-regulation has awful consequences. In this sense, Voorhoeve et al., (Voorhoeve et al., 2007) found increased levels of hsa-miR-371, miR-372 and miR-373 in TGCTs. Over-expression of these miRNAs down-regulate a tumor suppressor gene expression involved in RAS oncogene pathway. Besides, hsa-miR-373 has been identified as a cell migration factor and together with hsa-miR-520c promoted tumor invasion and metastasis (Huang et al., 2008; Negrini and Calin, 2008).

Further studies will be necessaries to identify the exact role of all these miRNAs in testicular cancer, but their expression profiles could be informative checkpoint for diagnosis. Serum biomarker monitoring is employed for diagnosis of TGCTs. More than a $50 \%$ of TGCT patients have increased levels of $\alpha$-fetoprotein, human chorionic gonadotropin and lactate dehydrogenase, however the lack of an increase does not exclude TGCT (Albers et al., 2011). It is necessary for a good prognosis to found specific biomarkers that permit a best diagnosis for TGCTs. As miRNAs presents a high stability in blood and other body fluids, could be good candidates to be used as biomarkers (Gilad et al., 2008; Brase et al., 2010; Wang et al., 2012; Zhang et al., 2012).

Approximately $45 \%$ of the human genome is composed of repetitive elements, which consist of interspersed repeats and tandem repeats (Jordan et al., 2003). LINE-1 and Alu are two major DNA repetitive elements: LINE-1 is a long group of interspersed nucleotide elements that constitutes at least $18 \%$ of the human genome (Kazazian, 2004). Alu and LINE1 elements are normally heavily methylated, and contain much of the $\mathrm{CpG}$ methylation found in normal human tissues (Kazazian, 2004) both LINE-1 and Alu repeats were extensively unmethylated in seminomatous TGCTs, whereas in non-seminomatous TGCTs, including two EC cell lines, the LINE-1 sequence was extensively unmethylated, but Alu elements were methylated (Ushida et al., 2012). Therefore, as piRNAs are key molecules involved in the regulation of the transposable elements in germ line, the altered patterns of piRNAs in germ cells as consequence of EDs exposure represents an intriguing avenue of exploration.

\section{Effects of EDs on miRNA expression profiles}

As response to other external input, such as chemical drugs, EDs can deregulate the expression and physiological pathways of small non-coding RNAs (Hudder and Novak, 2008; Zhang and Dolan, 2010; Majumder and Jacob, 2011). Besides the direct action of EDs on the transcriptional regulation of multiple genes encoding proteins, the EDs could alter the balance of the fine posttranscriptional regulation of $m R N A s$ mediated by non-coding small RNAs such as miRNAs. The action of deregulation of expression and accumulation of miRNAs by EDs can be carried out through by direct agonistic or antagonistic interactions with hormone receptors (HRs), which in turn regulate the expression of miRNAs or their biogenesis. In this sense, hormone sensitive cells exposed in vitro to estrogens (E2) shown deregulation of miRNAs. Some miRNAs are transcribed from polycistronic genes such as hsa-miR-17-92 cluster encodes 6 miRNAs (hsa-miR-17, miR-18a, miR-19a, miR20a, miR-19b-1, and miR-92-1). The pri-miRNA of this cluster and the mir-106a-363 paralogue cluster are upregulated by the ERo in breast cancer cells. Interestingly, the regulation occurs at the processing of primary forms to mature forms of miRNAs, as the pre-miR-18a is accumulated in ER $\alpha$-positive and not $\mathrm{ER} \beta$-positive breast cancers (Castellano et al., 2009). Furthermore, hsa-miR 18a regulates negatively ERa due to targeting of this miRNA in the ERa mRNA. In this context, previous studies reported that human miR-206 regulates the post-transcriptional expression of specific HRs as the ERa but not the $E R b$, inhibiting the expression of hsa-miR-206 the presence of ER $\alpha$ agonists, also indicating a feed-back regulation pathway (Adams et al., 2007). In addition to the interaction between ERs and miRNAs in breast cancer, new studies show the association of miRNAs with other steroid receptors such as androgen receptor, progesterone receptor, glucocorticoid receptor in non-breast cancers (see review by (Tessel et al., 2010).

Independently of the interaction between HRs and specific miRNAs, impaired biogenesis of miRNAs can be hormonally mediated. The processing of miRNAs can be repressed by the binding of DROSHA to ER $\alpha$ (Yamagata et al., 2009). In some hormonedependent cancers the global deregulation of miRNAs has been associated to the alterations in the expression of two key enzymes: DROSHA and DICER, involved in the miRNA processing. Down- 


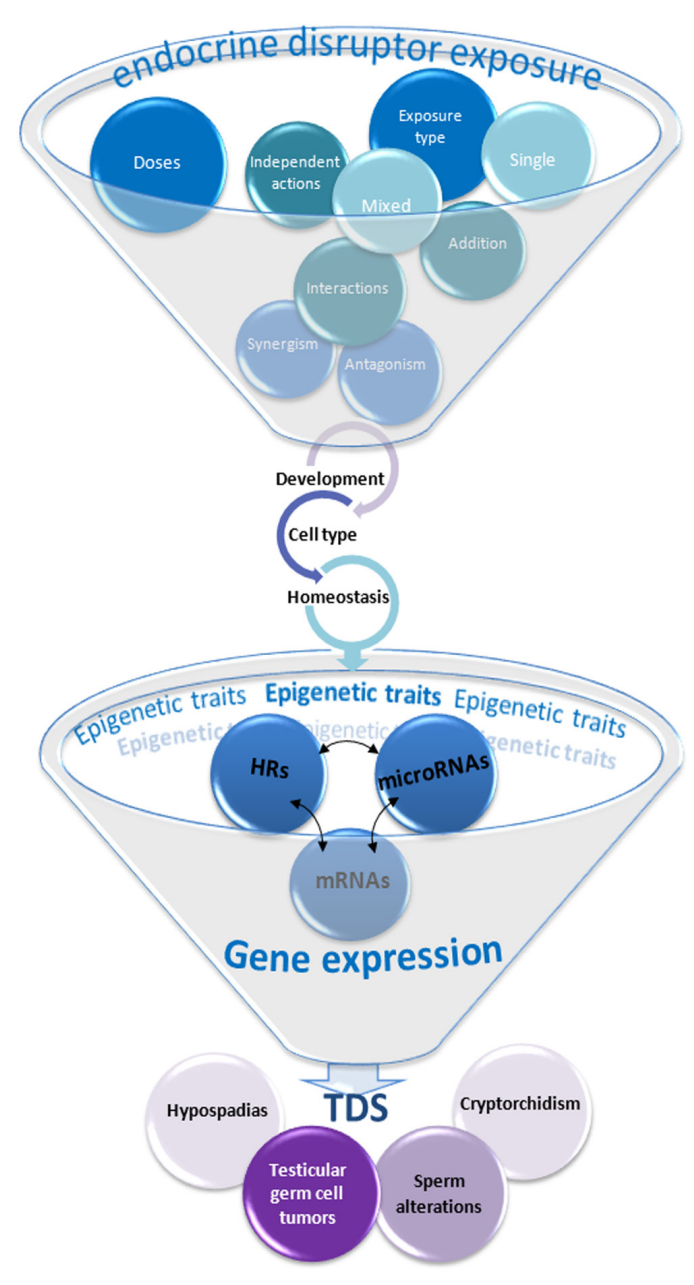

Fig. 3. Complex interactions between different factors and mechanisms of action of endocrine disruptors can lead to various pathologies in the development of testis, including germ cell tumors.

regulated DICER has been found in breast cancers (Grelier et al., 2009) or both DROSHA and DICER in ovarian cancers (Merritt et al., 2008) and subtypes of breast cancers (Dedes et al., 2011). However, opposite regulation of DICER was detected in prostate adenocarcinoma (Chiosea et al., 2006).

Recent studies reported that two well known EDs such as DDT and BPA alter the pattern of expression of multiple miRNAs of human MCF-7 including the estrogen-regulated hsa-miR-21 considered as onco-miR in breast cancer (Tilghman et al., 2012). Altered expression profiles of miRNAs linked to EDs exposure were also observed (Ficociello et al., 2010; Choi et al., 2011; Zhang and $\mathrm{Ho}, 2011)$. Specifically, it was observed overexpression of hsa-miR-146a in two placental cell lines in response to BPA exposure (Avissar-Whiting et al., 2010). Such overexpression, leads slower proliferation and increase the sensitivity to other damaging compounds (Avissar-Whiting et al., 2010). Furthermore, other miRNAs seem to be affected by BPA exposure. Three members of let-7 miRNA family increased their expression levels after the BPA exposure (Avissar-Whiting et al., 2010). As mentioned above, the equilibrium among let-7 family members and LIN-28 is critical for regulating the differentiated cell state. Changes in this equilibrium, may originate altered rates of cell proliferation (Melton et al., 2010; Newman and Hammond, 2010; Viswanathan and Daley, 2010; Wang et al., 2010; Chen et al., 2011; Pan et al., 2011). However, let-7 is considered as tumor suppressor (Zhang et al., 2007) and consequently the possible effect of deregulation of let-7 BPAmediated in testis could have be involved in other pathologies of TDS different to TGCTs. Similar alteration in miRNA expression has been reported in Sertoli cells exposed to nonylphenol. A third of miRNAs analyzed showed altered expression after exposure to this ED (Choi et al., 2011).

Recent reports show that epigenomic alterations may be parallel to those found in miRNA profiles and explained by crosstalk between epigenetic regulation and regulation of miRNA expression (Chuang and Jones, 2007; Fabbri, 2008), including specific patterns in testis (Schilling and Rehli, 2007).

All these studies clearly indicate a correlation between miRNA expression, and as a result on the corresponding products of the mRNA targets, and the hormone regulation pathways. Consequently, external factors with potential effects on hormonal balance, such as EDs, can alter the expression of miRNAs and hence the levels of mRNAs and the corresponding coded proteins. The harmful effects of EDs in miRNA expression profiles may be additional cause of altered proliferation cell rates on the reproductive system and potential source of TGCTs.

\section{Concluding remarks}

In mammals, testis development and germ cell fate is a complex and highly regulated genetically from early embryonic stages to adulthood (Kimble and Page, 2007). Consequently, disturbances in any of the regulatory pathways involved functional changes mediated by deregulation of gene expression, leading to reproductive dysfunctions and pathologies such as testicular cancer (Fig 3). In turn, the different regulatory mechanisms, including hormones, operate in a variable way in different stages of development. What is evident is that from the beginning of the primordial germ cell formation and differentiation in embryonic life there are key windows in the process, and therefore there are points of high risk susceptible of deleterious disruption by environmental signals.

The EDs and other potential reprotoxicants can alter the homeostasis necessary for correct testicular development and normal differentiation of germ cells but at different levels and developmental windows. Moreover, the synergistic effects of combinations of these compounds broaden the landscape of potential risk. The mechanisms of action of these compounds, leading to various pathologies in male gonadal development and function are multiple, but with a common core as deregulation of the expression of multiple genes. In these dysfunctional processes, different pathways could be affected: by direct action on transcriptional regulators, potentially mediated by hormones, and/or acting as post-transcriptional regulators such as those that affect miRNAs and piRNAs. Moreover, epigenetic deregulation may generate changes that in some cases may be inherited and transmitted transgenerationally (Youngson and Whitelaw, 2008). All these factors could contribute to the aetiology of pathologies manifested as germ cell tumors, along with intrinsic risk genomic factors in individuals or populations.

All this complex network of cause-effect can be evidenced by new high throughput approaches at molecular, cellular and developmental levels. However, considering the difficulties in the 
implementation of in vitro systems in germ cells development, the abundance and increased risk factors in our environment and their additive or synergistic effects, the goal is foreseen a long way but as a great challenge.

\section{Acknowledgements}

M.A. B-E. was supported by Postdoctoral Grant from CONACYT (165418, National Council of Science and Technology, Mexico. LALF was supported by a Miguel Servet grant from Instituto de Salud Carlos III (CP06 100267). Gene expression and effects of endocrine disruptors on testis development studies in the del Mazo's laboratory have been supported by grants from EC (QLK4-CT-2002-02403); CEFIC-LRi; MEDDTL (11-MRES-PNRPE-9CVS-072) France, and CSIC (PIE 201020E016), Spain.

\section{References}

ADAMS, B.D., FURNEAUX, H. and WHITE, B.A. (2007). The micro-ribonucleic acid (miRNA) miR-206 targets the human estrogen receptor-alpha (ERalpha) and represses ERalpha messenger RNA and protein expression in breast cancer cell lines. Mol Endocrinol 21: 1132-1147.

ALBERS, P., ALBRECHT, W., ALGABA, F., BOKEMEYER, C., COHN-CEDERMARK, G., FIZAZI, K., HORWICH, A. and LAGUNA, M.P. (2011). EAU guidelines on testicular cancer: 2011 update. Eur Urol 60: 304-319.

ALMSTRUP, K., HOEI-HANSEN, C.E., WIRKNER, U., BLAKE, J., SCHWAGER, C., ANSORGE, W., NIELSEN, J.E., SKAKKEBAEK, N.E., RAJPERT-DE MEYTS, E. and LEFFERS, H. (2004). Embryonic stem cell-like features of testicular carcinoma in situ revealed by genome-wide gene expression profiling. Cancer Res 64: 4736-4743.

AMBROS, V. (2001). microRNAs: tiny regulators with great potential. Cell107: 823-826.

ANDERSON, A.M., CARTER, K.W., ANDERSON, D. and WISE, M.J. (2012). Coexpression of nuclear receptors and histone methylation modifying genes in the testis: implications for endocrine disruptor modes of action. PLOS ONE7: e34158.

ANWAY, M.D., CUPP, A.S., UZUMCU, M. and SKINNER, M.K. (2005). Epigenetic transgenerational actions of endocrine disruptors and male fertility. Science 308: 1466-1469.

ANWAY, M.D., LEATHERS, C. and SKINNER, M.K. (2006). Endocrine disruptor vinclozolin induced epigenetic transgenerational adult-onset disease. Endocrinology 147: 5515-5523.

ARAVIN, A., GAIDATZIS, D., PFEFFER, S., LAGOS-QUINTANA, M., LANDGRAF, P., IOVINO, N., MORRIS, P., BROWNSTEIN, M.J., KURAMOCHI-MIYAGAWA, S., NAKANO, T. et al., (2006). A novel class of small RNAs bind to MILI protein in mouse testes. Nature 442: 203-207.

ASKLUND, C., JORGENSEN, N., KOLD JENSEN, T. and SKAKKEBAEK, N.E. (2004). Biology and epidemiology of testicular dysgenesis syndrome. BJU Int 93 Suppl 3: 6-11.

AVISSAR-WHITING, M., VEIGA, K.R., UHL, K.M., MACCANI, M.A., GAGNE, L.A., MOEN, E.L. and MARSIT, C.J. (2010). Bisphenol A exposure leads to specific microRNA alterations in placental cells. Reprod Toxicol 29: 401-406.

BANNISTER, A.J. and KOUZARIDES, T. (2011). Regulation of chromatin by histone modifications. Cell Res 21: 381-395.

BENTWICH, I. (2005). Prediction and validation of microRNAs and their targets. FEBS Lett 579: 5904-5910.

BENTWICH, I., AVNIEL, A., KAROV, Y., AHARONOV, R., GILAD, S., BARAD, O., BARZILAI, A., EINAT, P., EINAV, U., MEIRI, E. et al., (2005). Identification of hundreds of conserved and nonconserved human microRNAs. Nat Genet37:766-770.

BIRD, A., TAGGART, M., FROMMER, M., MILLER, O.J. and MACLEOD, D. (1985). A fraction of the mouse genome that is derived from islands of nonmethylated, CpG-rich DNA. Cell 40: 91-99.

BIRD, A.P. and WOLFFE, A.P. (1999). Methylation-induced repression--belts, braces, and chromatin. Cell 99: 451-454.

BLOW, M.J., GROCOCK, R.J., VAN DONGEN, S., ENRIGHT, A.J., DICKS, E., FUTREAL, P.A., WOOSTER, R. and STRATTON, M.R. (2006). RNA editing of human microRNAs. Genome Biol 7: R27.

BORGEL, J., GUIBERT, S., LI, Y., CHIBA, H., SCHUBELER, D., SASAKI, H., FORNE,
T. and WEBER, M. (2010). Targets and dynamics of promoter DNA methylation during early mouse development. Nat Genet 42: 1093-1100.

BRASE, J.C., WUTTIG, D., KUNER, R. and SULTMANN, H. (2010). Serum microRNAs as non-invasive biomarkers for cancer. Mol Cancer 9: 306.

BREHM, A., OVITT, C.E. and SCHOLER, H.R. (1998). Oct-4: more than just a POUerful marker of the mammalian germline? APMISA 106: 114-24; discussion 124-126.

BRENNAN, J. and CAPEL, B. (2004). One tissue, two fates: molecular genetic events that underlie testis versus ovary development. Nat Rev Genet 5: 509-521.

BROMER, J.G., ZHOU, Y., TAYLOR, M.B., DOHERTY, L. and TAYLOR, H.S. (2010). Bisphenol-A exposure in utero leads to epigenetic alterations in the developmental programming of uterine estrogen response. FASEB J 24: 2273-2280.

CALIN, G.A. and CROCE, C.M. (2006). MicroRNA signatures in human cancers. Nat Rev Cancer 6: 857-66.

CAO, C., PAYNE, K., LEE-KWON, W., ZHANG, Z., LIM, S.W., HAMLYN, J., BLAUSTEIN, M.P., KWON, H.M. and PALLONE, T.L. (2009). Chronic ouabain treatment induces vasa recta endothelial dysfunction in the rat. Am J Physiol Renal Physio 296: F98-F106.

CARLSEN, E., GIWERCMAN, A., KEIDING, N. and SKAKKEBAEK, N.E. (1992) Evidence for decreasing quality of semen during past 50 years. BMJ305: 609-613.

CASTELLANO, L., GIAMAS, G., JACOB, J., COOMBES, R.C., LUCCHESI, W., THIRUCHELVAM, P., BARTON, G., JIAO, L.R., WAIT, R., WAXMAN, J. et al., (2009). The estrogen receptor-alpha-induced microRNA signature regulates itself and its transcriptional response. Proc Natl Acad Sci USA 106: 15732-15737.

CLEMENT, T.M., SAVENKOVA, M.I., SETTLES, M., ANWAY, M.D. and SKINNER, M.K. (2010). Alterations in the developing testis transcriptome following embryonic vinclozolin exposure. Reprod Toxicol 30: 353-364.

COLBORN, T. and CLEMENT, C. (1992). Chemically induced alterations in sexual development: the wildlife/human connection. Princeton Scientific Publishing, Princeton (NJ)

COOK, M.S., MUNGER, S.C., NADEAU, J.H. and CAPEL, B. (2011). Regulation of male germ cell cycle arrest and differentiation by DND1 is modulated by genetic background. Development 138: 23-32.

COSTA, F.F. (2008). Non-coding RNAs, epigenetics and complexity. Gene 410: 9-17.

CROSS, S.H. and BIRD, A.P. (1995). CpG islands and genes. Curr Opin Genet Dev 5: 309-314.

CUPP, A.S., UZUMCU, M., SUZUKI, H., DIRKS, K., PHILLIPS, B. and SKINNER, M.K (2003). Effect of transient embryonic in vivo exposure to the endocrine disruptor methoxychlor on embryonic and postnatal testis development. JAndrol24:736-745.

CHANDLER, K.J., BARRIER, M., JEFFAY, S., NICHOLS, H.P., KLEINSTREUER, N.C., SINGH, A.V., REIF, D.M., SIPES, N.S., JUDSON, R.S., DIX, D.J. et al., (2011). Evaluation of 309 environmental chemicals using a mouse embryonic stem cell adherent cell differentiation and cytotoxicity assay. PLOSONE6: e18540.

CHANG, T.C., ZEITELS, L.R., HWANG, H.W., CHIVUKULA, R.R., WENTZEL, E.A., DEWS, M., JUNG, J., GAO, P., DANG, C.V., BEER, M.A. et al., (2009). Lin-28B transactivation is necessary for Myc-mediated let-7 repression and proliferation. Proc Natl Acad Sci USA 106: 3384-3389.

CHEN, A.X., YU, K.D., FAN, L., LI, J.Y., YANG, C., HUANG, A.J. and SHAO, Z.M. (2011). Germline genetic variants disturbing the Let-7/LIN28 double-negative feedback loop alter breast cancer susceptibility. PLoS Genet 7: e1002259.

CHIA, V.M., LI, Y., QURAISHI, S.M., GRAUBARD, B.I., FIGUEROA, J.D., WEBER, J.P., CHANOCK, S.J., RUBERTONE, M.V., ERICKSON, R.L. and MCGLYNN, K.A. (2010). Effect modification of endocrine disruptors and testicular germ cell tumour risk by hormone-metabolizing genes. Int $J$ Androl 33: 588-596.

CHIOSEA, S., JELEZCOVA, E., CHANDRAN, U., ACQUAFONDATA, M., MCHALE, T., SOBOL, R.W. and DHIR, R. (2006). Up-regulation of dicer, a component of the MicroRNA machinery, in prostate adenocarcinoma. Am J Pathol 169: 1812-1820.

CHOI, J.S., OH, J.H., PARK, H.J., CHOI, M.S., PARK, S.M., KANG, S.J., OH, M.J. KIM, S.J., HWANG, S.Y. and YOON, S. (2011). miRNA regulation of cytotoxic effects in mouse Sertoli cells exposed to nonylphenol. Reprod Biol Endocrino/9: 126

CHUA, J.H., ARMUGAM, A. and JEYASEELAN, K. (2009). MicroRNAs: biogenesis, function and applications. Curr Opin Mol Ther 11: 189-199.

CHUANG, J.C. and JONES, P.A. (2007). Epigenetics and microRNAs. Pediatr Res 61: 24R-29R.

DE CARVALHO, D.D., YOU, J.S. and JONES, P.A. (2010). DNA methylation and cellular reprogramming. Trends Cell Biol 20: 609-617. 
DE FELICI, M. (2001). Twenty years of research on primordial germ cells. Int J Dev Biol 45: 519-522.

DE FELICI, M. (2009). Primordial germ cell biology at the beginning of the XXI century. Int J Dev Biol 53: 891-894.

DE FELICI, M. (2011). Nuclear reprogramming in mouse primordial germ cells: epigenetic contribution. Stem Cells Int 2011: 425863.

DE FELICI, M. (2012). Origin, migration and proliferation of human primordial germ cells. In Oogenesis, (ed. GOTICCHIO, G.). Springer-Verlag, London.

DE FELICI, M. and FARINI, D. (2012). The control of cell cycle in mouse primordial germ cells: old and new players. Curr Pharm Des 18: 233-244.

DE JONG, J., STOOP, H., DOHLE, G.R., BANGMA, C.H., KLIFFEN, M., VANESSER, J.W., VAN DEN BENT, M., KROS, J.M., OOSTERHUIS, J.W. and LOOIJENGA, L.H. (2005). Diagnostic value of OCT3/4 for pre-invasive and invasive testicular germ cell tumours. J Pathol 206: 242-249.

DE LUIS, O. and DEL MAZO, J. (1998). Gene expression of mouse M1 and M2 pyruvate kinase isoenzymes correlates with differential poly[A] tract extension of their mRNAs during the development of spermatogenesis. Biochim Biophys Acta 1396: 294-305.

DEDES, K.J., NATRAJAN, R., LAMBROS, M.B., GEYER, F.C., LOPEZ-GARCIA, M.A., SAVAGE, K., JONES, R.L. and REIS-FILHO, J.S. (2011). Down-regulation of the miRNA master regulators Drosha and Dicer is associated with specific subgroups of breast cancer. Eur J Cancer 47: 138-150.

DOLINOY, D.C., DAS, R., WEIDMAN, J.R. and JIRTLE, R.L. (2007a). Metastable epialleles, imprinting, and the fetal origins of adult diseases. Pediatr Res 61:30R-37R.

DOLINOY, D.C., HUANG, D. and JIRTLE, R.L. (2007b). Maternal nutrient supplementation counteracts bisphenol A-induced DNA hypomethylation in early development. Proc Natl Acad Sci USA 104: 13056-13061.

DONOVAN, P.J. (1994). Growth factor regulation of mouse primordial germ cell development. Curr Top Dev Biol 29: 189-225.

DONOVAN, P.J. and DE MIGUEL, M.P. (2003). Turning germ cells into stem cells. Curr Opin Genet Dev 13: 463-471.

EDWARDS, T.M. and MYERS, J.P. (2007). Environmental exposures and gene regulation in disease etiology. Environ Health Perspect 115: 1264-1270.

ESTELLER, M. (2007). Cancer epigenomics: DNA methylomes and histone-modification maps. Nat Rev Genet 8: 286-298.

FABBRI, M. (2008). MicroRNAs and cancer epigenetics. Curr Opin Investig Drugs 9: $583-590$.

FEIL, R. and FRAGA, M.F. (2012). Epigenetics and the environment: emerging patterns and implications. Nat Rev Genet 13: 97-109.

FICOCIELLO, B., STURCHIO, E., MINOIA, C., CASORRI, L., IMBRIANI, P. and SIGNORINI, S. (2010). [Epigenetics and environmental exposure to xenobiotics]. G Ital Med Lav Ergon 32: 13-22.

FRAGA, M.F., BALLESTAR, E., PAZ, M.F., ROPERO, S., SETIEN, F., BALLESTAR, M.L., HEINE-SUNER, D., CIGUDOSA, J.C., URIOSTE, M., BENITEZ, J. et al., (2005). Epigenetic differences arise during the lifetime of monozygotic twins. Proc Natl Acad Sci USA 102: 10604-10609.

FRANCOIS, E., WANG, D.Y., FULTHORPE, R., LISS, S.N. and EDWARDS, E.A. (2003). DNA microarrays for detecting endocrine-disrupting compounds. Biotechnol Adv 22: 17-26.

GARCIA-LOPEZ, J. and DEL MAZO, J. (2012). Expression dynamics of microRNA biogenesis during preimplantation mouse development. Biochim Biophys Acta 1819: 847-854.

GASHAW, I., DUSHAJ, O., BEHR, R., BIERMANN, K., BREHM, R., RUBBEN, H., GROBHOLZ, R., SCHMID, K.W., BERGMANN, M. and WINTERHAGER, E. (2007). Novel germ cell markers characterize testicular seminoma and fetal testis. Mol Hum Reprod 13: 721-727.

GASHAW, I., GRUMMER, R., KLEIN-HITPASS, L., DUSHAJ, O., BERGMANN, M., BREHM, R., GROBHOLZ, R., KLIESCH, S., NEUVIANS, T.P., SCHMID, K.W. et al., (2005). Gene signatures of testicular seminoma with emphasis on expression of ets variant gene 4. Cell Mol Life Sci 62: 2359-2368

GERSON, S.L. (2004). MGMT: its role in cancer aetiology and cancer therapeutics. Nat Rev Cancer 4: 296-307.

GIBSON, G. (2008). The environmental contribution to gene expression profiles. Nat Rev Genet 9: 575-581.

GIDEKEL, S. and BERGMAN, Y. (2002). A unique developmental pattern of Oct-3/4
DNA methylation is controlled by a cis-demodification element. J Biol Chem 277 34521-34530.

GIDEKEL, S., PIZOV, G., BERGMAN, Y. and PIKARSKY, E. (2003). Oct-3/4 is a dose-dependent oncogenic fate determinant. Cancer Cell 4: 361-370.

GIGLIO, M., MEDICA, M., DE ROSE, A.F., GERMINALE, F., RAVETTI, J.L. and CARMIGNANI, G. (2003). Testicular sertoli cell tumours and relative sub-types. Analysis of clinical and prognostic features. Urol Int 70: 205-210.

GILAD, S., MEIRI, E., YOGEV, Y., BENJAMIN, S., LEBANONY, D., YERUSHALMI, N., BENJAMIN, H., KUSHNIR, M., CHOLAKH, H., MELAMED, N. et al., (2008). Serum microRNAs are promising novel biomarkers. PLoS One 3: e3148.

GILBERT, D., RAPLEY, E. and SHIPLEY, J. (2011). Testicular germ cell tumours: predisposition genes and the male germ cell niche. Nat Rev Cancer 11: 278-288.

GILLIS, A.J., STOOP, H., BIERMANN, K., VAN GURP, R.J., SWARTZMAN, E., CRIBBES, S., FERLINZ, A., SHANNON, M., OOSTERHUIS, J.W. and LOOIJENGA, L.H. (2011). Expression and interdependencies of pluripotency factors LIN28, OCT3/4, NANOG and SOX2 in human testicular germ cells and tumours of the testis. Int $J$ Androl 34: e160-e174.

GILLIS, A.J., STOOP, H.J., HERSMUS, R., OOSTERHUIS, J.W., SUN, Y., CHEN, C., GUENTHER, S., SHERLOCK, J., VELTMAN, I., BAETEN, J. et al., (2007) High-throughput microRNAome analysis in human germ cell tumours. J Pathol 213: 319-28.

GIRARD, A., SACHIDANANDAM, R., HANNON, G.J. and CARMELL, M.A. (2006). A germline-specific class of small RNAs binds mammalian Piwi proteins. Nature 442: 199-202

GODIN, I., DEED, R., COOKE, J., ZSEBO, K., DEXTER, M. and WYLIE, C.C. (1991). Effects of the steel gene product on mouse primordial germ cells in culture. Nature 352: 807-809.

GONZALEZ-GONZALEZ, E., LOPEZ-CASAS, P.P. and DEL MAZO, J. (2008). The expression patterns of genes involved in the RNAi pathways are tissue-dependent and differ in the germ and somatic cells of mouse testis. Biochim Biophys Acta 1779: 306-311.

GREENE, M.H., KRATZ, C.P., MAI, P.L., MUELLER, C., PETERS, J.A., BRATSLAVSKY, G., LING, A., CHOYKE, P.M., PREMKUMAR, A., BRACCI, J. et al., (2010). Familial testicular germ cell tumors in adults: 2010 summary of genetic risk factors and clinical phenotype. Endocr Relat Cancer 17: R109-R121.

GREER, E.L. and SHI, Y. (2012). Histone methylation: a dynamic mark in health, disease and inheritance. Nat Rev Genet 13: 343-357.

GRELIER, G., VOIRIN, N., AY, A.S., COX, D.G., CHABAUD, S., TREILLEUX, I., LEON-GODDARD, S., RIMOKH, R., MIKAELIAN, I., VENOUX, C. et al., (2009). Prognostic value of Dicer expression in human breast cancers and association with the mesenchymal phenotype. Br J Cancer 101: 673-683.

GRIVNA, S.T., BEYRET, E., WANG, Z. and LIN, H. (2006). A novel class of small RNAs in mouse spermatogenic cells. Genes Dev 20: 1709-1714.

GUARNIERI, D.J. and DILEONE, R.J. (2008). MicroRNAs: a new class of gene regulators. Ann Med 40: 197-208.

HACKETT, J.A., ZYLICZ, J.J. and SURANI, M.A. (2012). Parallel mechanisms of epigenetic reprogramming in the germline. Trends Genet 28: 164-174.

HAGAN, J.P., PISKOUNOVA, E. and GREGORY, R.I. (2009). Lin28 recruits the TUTase Zcchc11 to inhibit let-7 maturation in mouse embryonic stem cells. Nat Struct Mol Biol 16: 1021-1025.

HART, A.H., HARTLEY, L., PARKER, K., IBRAHIM, M., LOOIJENGA, L.H., PAUCHNIK, M., CHOW, C.W. and ROBB, L. (2005). The pluripotency homeobox gene NANOG is expressed in human germ cell tumors. Cancer 104: 2092-2098.

HAYASHI, K., CHUVADE SOUSA LOPES, S.M., KANEDA, M., TANG, F., HAJKOVA, P., LAO, K., O'CARROLL, D., DAS, P.P., TARAKHOVSKY, A., MISKA, E.A. et al., (2008). MicroRNA biogenesis is required for mouse primordial germ cell development and spermatogenesis. PLOS ONE 3: e1738.

HE, Z., KOKKINAKI, M., PANT, D., GALLICANO, G.I. and DYM, M. (2009). Small RNA molecules in the regulation of spermatogenesis. Reproduction 137: 901-911.

HEIJMANS, B.T., TOBI, E.W., LUMEY, L.H. and SLAGBOOM, P.E. (2009). The epigenome: archive of the prenatal environment. Epigenetics 4: 526-531.

HEO, I., JOO, C., CHO, J., HA, M., HAN, J. and KIM, V.N. (2008). Lin28 mediates the terminal uridylation of let-7 precursor MicroRNA. Mol Cell 32: 276-284.

HO, S.M., TANG, W.Y., BELMONTE DE FRAUSTO, J. and PRINS, G.S. (2006) Developmental exposure to estradiol and bisphenol A increases susceptibility to 
prostate carcinogenesis and epigenetically regulates phosphodiesterase type 4 variant 4. Cancer Res 66: 5624-5632.

HOEI-HANSEN, C.E., ALMSTRUP, K., NIELSEN, J.E., BRASK SONNE, S., GRAEM, N., SKAKKEBAEK, N.E., LEFFERS, H. and RAJPERT-DE MEYTS, E. (2005). Stem cell pluripotency factor NANOG is expressed in human fetal gonocytes, testicular carcinoma in situ and germ cell tumours. Histopathology 47: 48-56.

HONECKER, F., STOOP, H., DE KRIJGER, R.R., CHRIS LAU, Y.F., BOKEMEYER, C. and LOOIJENGA, L.H. (2004). Pathobiological implications of the expression of markers of testicular carcinoma in situ by fetal germ cells. J Pathol 203: 849-857.

HONORIO, S., AGATHANGGELOU, A., WERNERT, N., ROTHE, M., MAHER, E.R. and LATIF, F. (2003). Frequent epigenetic inactivation of the RASSF1A tumour suppressor gene in testicular tumours and distinct methylation profiles of seminoma and nonseminoma testicular germ cell tumours. Oncogene 22: 461-466.

HOU, L., WANG, D. and BACCARELLI, A. (2011). Environmental chemicals and microRNAs. Mutat Res 714: 105-112.

HOU, L., ZHANG, X., WANG, D. and BACCARELLI, A. (2012). Environmental chemical exposures and human epigenetics. Int J Epidemiol 41: 79-105.

HOULDSWORTH, J., KORKOLA, J.E., BOSL, G.J. and CHAGANTI, R.S. (2006) Biology and genetics of adult male germ cell tumors. J Clin Oncol 24: 5512-5518.

HUANG, Q., GUMIREDDY, K., SCHRIER, M., LE SAGE, C., NAGEL, R., NAIR, S., EGAN, D.A., LI, A., HUANG, G., KLEIN-SZANTO, A.J. et al., (2008). The microRNAs miR-373 and miR-520c promote tumour invasion and metastasis. Nat Cell Biol 10: 202-210

HUDDER, A. and NOVAK, R.F. (2008). miRNAs: effectors of environmental influences on gene expression and disease. Toxicol Sci 103: 228-240.

HUSSAIN, S.A., MA, Y.T., PALMER, D.H., HUTTON, P. and CULLEN, M.H. (2008). Biology of testicular germ cell tumors. Expert Rev Anticancer Ther 8: 1659-1673.

HUSTIN, J., COLLETTE, J. and FRANCHIMONT, P. (1987). Immunohistochemical demonstration of placental alkaline phosphatase in various states of testicular development and in germ cell tumours. Int J Androl 10: 29-35.

HUYGHE, E., MATSUDA, T. and THONNEAU, P. (2003). Increasing incidence of testicular cancer worldwide: a review. J Urol 170: 5-11.

IGUCHI, T., WATANABE, H. and KATSU, Y. (2006). Application of ecotoxicogenomics for studying endocrine disruption in vertebrates and invertebrates. Environ Health Perspect 114 Suppl 1: 101-105.

IGUCHI, T., WATANABE, H. and KATSU, Y. (2007). Toxicogenomics and ecotoxicogenomics for studying endocrine disruption and basic biology. Gen Comp Endocrinol 153: 25-29.

IONA, S., KLINGER, F.G., SISTI, R., CICCALESE, R., NUNZIATA, A. and DE FELICI, M. (2002). A comparative study of cytotoxic effects of $\mathrm{N}$-ethyl-N-nitrosourea, adriamycin, and mono-(2-ethylhexyl)phthalate on mouse primordial germ cells. Cell Biol Toxicol 18: 131-145.

IZZOTTI, A., CALIN, G.A., ARRIGO, P., STEELE, V.E., CROCE, C.M. and DE FLORA, S. (2009a). Downregulation of microRNA expression in the lungs of rats exposed to cigarette smoke. FASEB J 23: 806-812.

IZZOTTI, A., CALIN, G.A., STEELE, V.E., CROCE, C.M. and DE FLORA, S. (2009b). Relationships of microRNA expression in mouse lung with age and exposure to cigarette smoke and light. FASEB J 23: 3243-3250.

JENUWEIN, T. and ALLIS, C.D. (2001). Translating the histone code. Science 293: 1074-1080.

JIANG, L.I. and NADEAU, J.H. (2001). 129/Sv mice--a model system for studying germ cell biology and testicular cancer. Mamm Genome 12: 89-94.

JOHNSON, S.M., GROSSHANS, H., SHINGARA, J., BYROM, M., JARVIS, R., CHENG, A., LABOURIER, E., REINERT, K.L., BROWN, D. and SLACK, F.J. (2005). RAS is regulated by the let-7 microRNA family. Cell 120: 635-647.

JORDAN, I.K., ROGOZIN, I.B., GLAZKO, G.V. and KOONIN, E.V. (2003). Origin of a substantial fraction of human regulatory sequences from transposable elements. Trends Genet 19: 68-72.

JUNG, S.M., CHU, P.H., SHIU, T.F., WU, H.H., KUO, T.T., CHU, J.J. and LIN, P.J. (2006). Expression of OCT4 in the primary germ cell tumors and thymoma in the mediastinum. Appl Immunohistochem Mol Morphol 14: 273-275.

KAZAZIAN, H.H., JR. (2004). Mobile elements: drivers of genome evolution. Science 303: 1626-1632.

KEDDE, M., STRASSER, M.J., BOLDAJIPOUR, B., OUDE VRIELINK, J.A., SLANCHEV, K., LE SAGE, C., NAGEL, R., VOORHOEVE, P.M., VAN DUIJSE, J.,
OROM, U.A. et al., (2007). RNA-binding protein Dnd1 inhibits microRNA access to target mRNA. Cell 131: 1273-1286.

KEEGAN, L.P., GALLO, A. and O'CONNELL, M.A. (2001). The many roles of an RNA editor. Nat Rev Genet 2: 869-878.

KELCE, W.R., MONOSSON, E., GAMCSIK, M.P., LAWS, S.C. and GRAY, L.E., JR (1994). Environmental hormone disruptors: evidence that vinclozolin developmental toxicity is mediated by antiandrogenic metabolites. Toxicol Appl Pharmacol 126: $276-285$

KEMPKENSTEFFEN, C., CHRISTOPH, F., WEIKERT, S., KRAUSE, H., KOLLERMANN, J., SCHOSTAK, M., MILLER, K. and SCHRADER, M. (2006). Epigenetic silencing of the putative tumor suppressor gene testisin in testicular germ cell tumors. J Cancer Res Clin Oncol 132: 765-770.

KIM, J.K., SAMARANAYAKE, M. and PRADHAN, S. (2009). Epigenetic mechanisms in mammals. Cell Mol Life Sci 66: 596-612.

KIM, V.N. (2006). Small RNAs just got bigger: Piwi-interacting RNAs (piRNAs) in mammalian testes. Genes Dev 20: 1993-1997.

KIMBLE, J. and PAGE, D.C. (2007). The mysteries of sexual identity. The germ cell's perspective. Science 316: 400-401.

KIMURA, T., SUZUKI, A., FUJITA, Y., YOMOGIDA, K., LOMELI, H., ASADA, N. IKEUCHI, M., NAGY, A., MAK, T.W. and NAKANO, T. (2003). Conditional loss of PTEN leads to testicular teratoma and enhances embryonic germ cell production. Development 130: 1691-1700.

KRISTENSEN, D.M., SONNE, S.B., OTTESEN, A.M., PERRETT, R.M., NIELSEN, J.E ALMSTRUP, K., SKAKKEBAEK, N.E., LEFFERS, H. and RAJPERT-DE MEYTS, E. (2008). Origin of pluripotent germ cell tumours: the role of microenvironment during embryonic development. Mol Cell Endocrinol 288: 111-118.

KUBICEK, S., SCHOTTA, G., LACHNER, M., SENGUPTA, R., KOHLMAIER, A. PEREZ-BURGOS, L., LINDERSON, Y., MARTENS, J.H., O'SULLIVAN, R.J., FODOR, B.D. et al., (2006). The role of histone modifications in epigenetic transitions during normal and perturbed development. Ernst Schering Res Found Workshop1-27.

LA SALA, G., FARINI, D. and DE FELICI, M. (2009). Proapoptotic effects of lindane on mouse primordial germ cells. Toxicol Sci 108: 445-451.

LA SALA, G., FARINI, D. and DE FELICI, M. (2010). Rapid estrogen signalling in mouse primordial germ cells. Exp Cell Res 316: 1716-1727.

LADOMERY, M.R., MADDOCKS, D.G. and WILSON, I.D. (2011). MicroRNAs: their discovery, biogenesis, function and potential use as biomarkers in non-invasive prenatal diagnostics. Int J Mol Epidemiol Genet 2: 253-260.

LAU, P.W. and MACRAE, I.J. (2009). The molecular machines that mediate microRNA maturation. J Cell Mol Med 13: 54-60.

LEE, Y.S. and DUTTA, A. (2007). The tumor suppressor microRNA let-7 represses the HMGA2 oncogene. Genes Dev 21: 1025-1030.

LESSARD, C., PENDOLA, J.K., HARTFORD, S.A., SCHIMENTI, J.C., HANDEL, M.A and EPPIG, J.J. (2004). New mouse genetic models for human contraceptive development. Cytogenet Genome Res 105: 222-227.

LEWIS, B.P., BURGE, C.B. and BARTEL, D.P. (2005). Conserved seed pairing, often flanked by adenosines, indicates that thousands of human genes are microRNA targets. Cell 120: 15-20

LI, S., HURSTING, S.D., DAVIS, B.J., MCLACHLAN, J.A. and BARRETT, J.C. (2003) Environmental exposure, DNA methylation, and gene regulation: lessons from diethylstilbesterol-induced cancers. Ann N Y Acad Sci 983: 161-169.

LOOIJENGA, L.H., GILLIS, A.J., STOOP, H., HERSMUS, R. and OOSTERHUIS, J.W. (2007a). Relevance of microRNAs in normal and malignant development, including human testicular germ cell tumours. Int J Andro/30: 304-314; discussion 314-315.

LOOIJENGA, L.H., GILLIS, A.J., STOOP, H.J., HERSMUS, R. and OOSTERHUIS J.W. (2007b). Chromosomes and expression in human testicular germ-cell tumors: insight into their cell of origin and pathogenesis. Ann N Y Acad Sci 1120: 187-214.

LOOIJENGA, L.H., STOOP, H., DE LEEUW, H.P., DE GOUVEIA BRAZAO, C.A., GILLIS, A.J., VAN ROOZENDAAL, K.E., VAN ZOELEN, E.J., WEBER, R.F., WOLFFENBUTTEL, K.P., VAN DEKKEN, H. et al., (2003a). POU5F1 (OCT3/4) identifies cells with pluripotent potential in human germ cell tumors. Cancer Res 63: 2244-2250

LOOIJENGA, L.H., ZAFARANA, G., GRYGALEWICZ, B., SUMMERSGILL, B., DEBIEC-RYCHTER, M., VELTMAN, J., SCHOENMAKERS, E.F., RODRIGUEZ, S., JAFER, O., CLARK, J. et al., (2003b). Role of gain of 12p in germ cell tumour development. APMIS111: 161-171; discussion 172-173. 
LOPEZ-CASAS, P.P., MIZRAK, S.C., LOPEZ-FERNANDEZ, L.A., PAZ, M., DE ROOIJ, D.G. and DEL MAZO, J. (2012). The effects of different endocrine disruptors defining compound-specific alterations of gene expression profiles in the developing testis. Reprod Toxicol 33: 106-115.

LU, L., KATSAROS, D., SHAVERDASHVILI, K., QIAN, B., WU, Y., DE LALONGRAIS, I.A., PRETI, M., MENATO, G. and YU, H. (2009). Pluripotent factor lin-28 and its homologue lin-28b in epithelial ovarian cancer and their associations with disease outcomes and expression of let-7a and IGF-II. Eur J Cancer 45: 2212-2218.

MAJUMDER, S. and JACOB, S.T. (2011). Emerging role of microRNAs in drug-resistant breast cancer. Gene Expr 15: 141-151.

MANTON, K.J., DOUGLAS, M.L., NETZEL-ARNETT, S., FITZPATRICK, D.R., NICOL, D.L., BOYD, A.W., CLEMENTS, J.A. and ANTALIS, T.M. (2005). Hypermethylation of the 5' $\mathrm{CpG}$ island of the gene encoding the serine protease Testisin promotes its loss in testicular tumorigenesis. Br J Cancer 92: 760-769.

MARTIN, G.M. (2009). Epigenetic gambling and epigenetic drift as an antagonistic pleiotropic mechanism of aging. Aging Cell 8: 761-764.

MATIN, A. and NADEAU, J.H. (2005). Search for testicular cancer gene hits deadend. Cell Cycle 4: 1136-1138.

MCGLYNN, K.A., QURAISHI, S.M., GRAUBARD, B.I., WEBER, J.P., RUBERTONE, M.V. and ERICKSON, R.L. (2008). Persistent organochlorine pesticides and risk of testicular germ cell tumors. J Natl Cancer Inst 100: 663-671.

MCGLYNN, K.A., QURAISHI, S.M., GRAUBARD, B.I., WEBER, J.P., RUBERTONE, M.V. and ERICKSON, R.L. (2009). Polychlorinated biphenyls and risk of testicular germ cell tumors. Cancer Res 69: 1901-1909.

MCIVER, S.C., ROMAN, S.D., NIXON, B. and MCLAUGHLIN, E.A. (2012). miRNA and mammalian male germ cells. Hum Reprod Update 18: 44-59.

MCLAREN, A. (2003). Primordial germ cells in the mouse. Dev Biol 262: 1-15.

MCLAREN, A. and LAWSON, K.A. (2005). How is the mouse germ-cell lineage established? Differentiation 73: 435-437.

MEISSNER, A. (2010). Epigenetic modifications in pluripotent and differentiated cells. Nat Biotechnol 28: 1079-1088.

MELTON, C., JUDSON, R.L. and BLELLOCH, R. (2010). Opposing microRNA families regulate self-renewal in mouse embryonic stem cells. Nature 463: 621-626.

MERRITT, W.M., LIN, Y.G., HAN, L.Y., KAMAT, A.A., SPANNUTH, W.A., SCHMANDT, R., URBAUER, D., PENNACCHIO, L.A., CHENG, J.F., NICK, A.M. et al., (2008). Dicer, Drosha, and outcomes in patients with ovarian cancer. N Engl J Med 359: 2641-2650.

MOE-BEHRENS, G.H., KLINGER, F.G., ESKILD, W., GROTMOL, T., HAUGEN, T.B. and DE FELICl, M. (2003). Akt/PTEN signaling mediates estrogen-dependent proliferation of primordial germ cells in vitro. Mol Endocrinol 17: 2630-2638.

MOHAMED, G.H., GELFOND, J.A., NICOLAS, M.M., BRAND, T.C., SARVIS, J.A., LEACH, R.J. and JOHNSON-PAIS, T.L. (2012). Genomic Characterization of Testis Cancer: Association of Alterations With Outcome of Clinical Stage 1 Mixed Germ Cell Nonseminomatous Germ Cell Tumor of the Testis. Urology 80: 485.e1-485.e5

MOSTOFI, F.K. (1973). Proceedings: Testicular tumors. Epidemiologic, etiologic, and pathologic features. Cancer 32: 1186-1201.

MOTZER, R.J., AGARWAL, N., BEARD, C., BHAYANI, S., BOLGER, G.B., BUYYOUNOUSKI, M.K., CARDUCCI, M.A., CHANG, S.S., CHOUEIRI, T.K., GUPTA, S. et al., (2012). Testicular cancer. J Natl Compr Canc Netw 10: 502-535.

MU, W. and ZHANG, W. (2012). Bioinformatic Resources of microRNA Sequences, Gene Targets, and Genetic Variation. Front Genet 3: 31.

NEGRINI, M. and CALIN, G.A. (2008). Breast cancer metastasis: a microRNA story. Breast Cancer Res 10: 203.

NEWMAN, M.A. and HAMMOND, S.M. (2010). Lin-28: an early embryonic sentinel that blocks Let-7 biogenesis. Int J Biochem Cell Biol 42: 1330-1333.

NEWMAN, M.A., THOMSON, J.M. and HAMMOND, S.M. (2008). Lin-28 interaction with the Let-7 precursor loop mediates regulated microRNA processing. RNA 14: 1539-1549.

NICHOLS, J., ZEVNIK, B., ANASTASSIADIS, K., NIWA, H., KLEWE-NEBENIUS, D., CHAMBERS, I., SCHOLER, H. and SMITH, A. (1998). Formation of pluripotent stem cells in the mammalian embryo depends on the POU transcription factor Oct4. Cell 95: 379-91.

NISHIKURA, K. (2010). Functions and regulation of RNAediting by ADAR deaminases. Annu Rev Biochem 79: 321-349.

NIWA, H. (2007). How is pluripotency determined and maintained? Development
134: 635-646

OHINATA, Y., PAYER, B., O'CARROLL, D., ANCELIN, K., ONO, Y., SANO, M. BARTON, S.C., OBUKHANYCH, T., NUSSENZWEIG, M., TARAKHOVSKY, A. et al., (2005). Blimp1 is a critical determinant of the germ cell lineage in mice. Nature 436: 207-213.

OKADA, K., KATAGIRI, T., TSUNODA, T., MIZUTANI, Y., SUZUKI, Y., KAMADA, M., FUJIOKA, T., SHUIN, T., MIKI, T. and NAKAMURA, Y. (2003). Analysis of gene-expression profiles in testicular seminomas using a genome-wide cDNA microarray. Int J Oncol 23: 1615-1635.

OKAMOTO, K. and KAWAKAMI, T. (2007). Epigenetic profile of testicular germ cell tumours. Int J Androl 30: 385-392; discussion 392.

OOSTERHUIS, J.W. and LOOIJENGA, L.H. (2005). Testicular germ-cell tumours in a broader perspective. Nat Rev Cancer 5: 210-222.

ORRENIUS, S. (2007). Reactive oxygen species in mitochondria-mediated cell death. Drug Metab Rev 39: 443-455.

PALMER, R.D., MURRAY, M.J., SAINI, H.K., VANDONGEN, S., ABREU-GOODGER, C., MURALIDHAR, B., PETT, M.R., THORNTON, C.M., NICHOLSON, J.C., ENRIGHT, A.J. et al., (2010). Malignant germ cell tumors display common microRNA profiles resulting in global changes in expression of messenger RNA targets. Cancer Res 70: 2911-2923.

PALUMBO, C., VAN ROOZENDAAL, K., GILLIS, A.J., VAN GURP, R.H., DE MUNNIK, H., OOSTERHUIS, J.W., VAN ZOELEN, E.J. and LOOIJENGA, L.H. (2002). Expression of the PDGF alpha-receptor $1.5 \mathrm{~kb}$ transcript, OCT-4, and c-KIT in human normal and malignant tissues. Implications for the early diagnosis of testicular germ cell tumours and for our understanding of regulatory mechanisms. J Pathol 196: 467-477.

PAN, L., GONG, Z., ZHONG, Z., DONG, Z., LIU, Q., LE, Y. and GUO, J. (2011). Lin28 reactivation is required for let-7 repression and proliferation in human small cell lung cancer cells. Mol Cell Biochem 355: 257-63.

PARK, S.Y. and JAMESON, J.L. (2005). Minireview: transcriptional regulation of gonadal development and differentiation. Endocrinology 146: 1035-1042.

PARRAGA, M. and DELMAZO, J. (2000). XYbp, a novel RING-finger protein, is a component of the XY body of spermatocytes and centrosomes. Mech Dev 90: 95-101.

PAYNE, A.H., HARDY, M.P. and RUSSELL, L.D. (1996). The Leydig cell. Cache River Press Vienna, IL.

PISKOUNOVA, E., VISWANATHAN, S.R., JANAS, M., LAPIERRE, R.J., DALEY, G.Q., SLIZ, P. and GREGORY, R.I. (2008). Determinants of microRNA processing inhibition by the developmentally regulated RNA-binding protein Lin28. J Biol Chem 283: 21310-21314.

POLANCO, J.C. and KOOPMAN, P. (2007). Sry and the hesitant beginnings of male development. Dev Biol 302: 13-24.

POPP, C., DEAN, W., FENG, S., COKUS, S.J., ANDREWS, S., PELLEGRINI, M., JACOBSEN, S.E. and REIK, W. (2010). Genome-wide erasure of DNA methylation in mouse primordial germ cells is affected by AID deficiency. Nature 463: 1101-5.

PORTELA, A. and ESTELLER, M. (2010). Epigenetic modifications and human disease. Nat Biotechnol 28: 1057-1068.

RAJASETHUPATHY, P., ANTONOV, I., SHERIDAN, R., FREY, S., SANDER, C., TUSCHL, T. and KANDEL, E.R. (2012). A Role for Neuronal piRNAs in the Epigenetic Control of Memory-Related Synaptic Plasticity. Cell 149: 693-707.

RAJPERT-DE MEYTS, E. (2006). Developmental model for the pathogenesis of testicular carcinoma in situ: genetic and environmental aspects. Hum Reprod Update 12: 303-323.

RAJPERT-DE MEYTS, E., JORGENSEN, N., BRONDUM-NIELSEN, K., MULLER, J. and SKAKKEBAEK, N.E. (1998). Developmental arrest of germ cells in the pathogenesis of germ cell neoplasia. APMIS 106: 198-204; discussion 204-206.

RAJPERT-DE MEYTS, E. and SKAKKEBAEK, N.E. (1994). Expression of the c-kit protein product in carcinoma-in-situ and invasive testicular germ cell tumours. Int J Androl 17: 85-92.

RICHBURG, J.H., JOHNSON, K.J., SCHOENFELD, H.A., MEISTRICH, M.L. and DIX, D.J. (2002). Defining the cellular and molecular mechanisms of toxicant action in the testis. Toxicol Lett 135: 167-183.

RICHIARDI, L., BELLOCCO, R., ADAMI, H.O., TORRANG, A., BARLOW, L., HAKULINEN, T., RAHU, M., STENGREVICS, A., STORM, H., TRETLI, S. et al., (2004). Testicular cancer incidence in eight northern European countries: secular and recent trends. Cancer Epidemiol Biomarkers Prev 13: 2157-2166.

RICHIE, J.P. (2005). OCT4 staining in testicular tumors. Asensitive and specific marker 
for seminoma and embryonal carcinoma. J Urol 174: 569-570.

RO, S., PARK, C., SANDERS, K.M., MCCARREY, J.R. and YAN, W. (2007). Cloning and expression profiling of testis-expressed microRNAs. Dev Biol 311: 592-602.

RODRIGUEZ, S., JAFER, O., GOKER, H., SUMMERSGILL, B.M., ZAFARANA, G., GILLIS, A.J., VAN GURP, R.J., OOSTERHUIS, J.W., LU, Y.J., HUDDART, R. et al., (2003). Expression profile of genes from 12p in testicular germ cell tumors of adolescents and adults associated with i(12p) and amplification at 12p11.2-p12.1 . Oncogene 22: 1880-1891.

ROSS, J.S., CARLSON, J.A. and BROCK, G. (2007). miRNA: the new gene silencer. Am J Clin Pathol 128: 830-836.

RUNYAN, C., SCHAIBLE, K., MOLYNEAUX, K., WANG, Z., LEVIN, L. and WYLIE, C. (2006). Steel factor controls midline cell death of primordial germ cells and is essential for their normal proliferation and migration. Development 133:4861-4869.

RYBAK, A., FUCHS, H., SMIRNOVA, L., BRANDT, C., POHL, E.E., NITSCH, R. and WULCZYN, F.G. (2008). A feedback loop comprising lin-28 and let-7 controls prelet-7 maturation during neural stem-cell commitment. Nat Cell Biol 10: 987-993.

SAITOU, M., BARTON, S.C. and SURANI, M.A. (2002). A molecular programme for the specification of germ cell fate in mice. Nature 418: 293-300.

SAITOU, M., PAYER, B., LANGE, U.C., ERHARDT, S., BARTON, S.C. and SURANI, M.A. (2003). Specification of germ cell fate in mice. Philos Trans $R$ Soc Lond $B$ Biol Sci 358: 1363-1370.

SANSAM, C.L., WELLS, K.S. and EMESON, R.B. (2003). Modulation of RNA editing by functional nucleolar sequestration of ADAR2. Proc Natl Acad Sci USA 100: 14018-14023.

SATO, F., TSUCHIYA, S., MELTZER, S.J. and SHIMIZU, K. (2011). MicroRNAs and epigenetics. FEBS J 278: 1598-1609.

SCHILLING, E. and REHLI, M. (2007). Global, comparative analysis of tissue-specific promoter $\mathrm{CpG}$ methylation. Genomics 90: 314-323.

SCHNEIDER, D.T., SCHUSTER, A.E., FRITSCH, M.K., HU, J., OLSON, T., LAUER, S., GOBEL, U. and PERLMAN, E.J. (2001). Multipoint imprinting analysis indicates a common precursor cell for gonadal and nongonadal pediatric germ cell tumors. Cancer Res 61: 7268-7276.

SCHNEIDER, S., KAUFMANN, W., BUESEN, R. and VAN RAVENZWAAY, B. (2008). Vinclozolin--the lack of a transgenerational effect after oral maternal exposure during organogenesis. Reprod Toxicol 25: 352-360.

SCHULTZ, N., HAMRA, F.K. and GARBERS, D.L. (2003). A multitude of genes expressed solely in meiotic or postmeiotic spermatogenic cells offers a myriad of contraceptive targets. Proc Natl Acad Sci USA 100: 12201-12206.

SELBACH, M., SCHWANHAUSSER, B., THIERFELDER, N., FANG, Z., KHANIN, R. and RAJEWSKY, N. (2008). Widespread changes in protein synthesis induced by microRNAs. Nature 455: 58-63.

SHARMA, S., KELLY, T.K. and JONES, P.A. (2010). Epigenetics in cancer. Carcinogenesis 31: 27-36.

SHARPE, R.M., MCKINNELL, C., KIVLIN, C. and FISHER, J.S. (2003). Proliferation and functional maturation of Sertoli cells, and their relevance to disorders of testis function in adulthood. Reproduction 125: 769-784.

SHARPE, R.M. and SKAKKEBAEK, N.E. (1993). Are oestrogens involved in falling sperm counts and disorders of the male reproductive tract? Lancet341:1392-1395.

SHEIKINE, Y., GENEGA, E., MELAMED, J., LEE, P., REUTER, V.E. and YE, H. (2012). Molecular genetics of testicular germ cell tumors. Am J Cancer Res 2: 153-167.

SIEGEL, R., DESANTIS, C., VIRGO, K., STEIN, K., MARIOTTO, A., SMITH, T., COOPER, D., GANSLER, T., LERRO, C., FEDEWA, S. et al., (2012). Cancer treatment and survivorship statistics. CA Cancer J Clin. 62: 220-241.

SIEVERS, S., ALEMAZKOUR, K., ZAHN, S., PERLMAN, E.J., GILLIS, A.J., LOOIJENGA, L.H., GOBEL, U. and SCHNEIDER, D.T. (2005). IGF2/H19 imprinting analysis of human germ cell tumors (GCTs) using the methylation-sensitive singlenucleotide primer extension method reflects the origin of GCTs in different stages of primordial germ cell development. Genes Chromosomes Cancer 44: 256-264.

SIKKA, S.C., RAJASEKARAN, M. and HELLSTROM, W.J. (1995). Role of oxidative stress and antioxidants in male infertility. J Androl 16: 464-468.

SIOMI, M.C., SATO, K., PEZIC, D. and ARAVIN, A.A. (2011). PIWI-interacting small RNAs: the vanguard of genome defence. Nat Rev Mol Cell Biol 12: 246-258.

SJOBLOM, T., WEST, A. and LAHDETIE, J. (1998). Apoptotic response of spermatogenic cells to the germ cell mutagens etoposide, adriamycin, and diepoxybutane. Environ Mol Mutagen 31: 133-148.
SKAKKEBAEK, N.E. (1972). Possible carcinoma-in-situ of the testis. Lancet2: 516-517

SKAKKEBAEK, N.E., RAJPERT-DE MEYTS, E. and MAIN, K.M. (2001). Testicular dysgenesis syndrome: an increasingly common developmental disorder with environmental aspects. Hum Reprod 16: 972-978.

SKINNER, M.K. (2007). Epigenetic transgenerational toxicology and germ cell disease. Int J Androl 30: 393-6; discussion 396-397.

SKINNER, M.K. and ANWAY, M.D. (2005). Seminiferous cord formation and germcell programming: epigenetic transgenerational actions of endocrine disruptors. Ann N Y Acad Sci 1061: 18-32.

SKINNER, M.K. and GRISWOLD, M.D. (2005). Sertoli Cell Biology. Academic Press, Amsterdam

SKINNER, M.K., MANIKKAM, M. and GUERRERO-BOSAGNA, C. (2011). Epigenetic transgenerational actions of endocrine disruptors. Reprod Toxicol 31: 337-343.

SMIRAGLIA, D.J., SZYMANSKA, J., KRAGGERUD, S.M., LOTHE, R.A., PELTOMAKI, P. and PLASS, C. (2002). Distinct epigenetic phenotypes in seminomatous and nonseminomatous testicular germ cell tumors. Oncogene 21: 3909-3916.

SMITH-SORENSEN, B., LIND, G.E., SKOTHEIM, R.I., FOSSA, S.D., FODSTAD, O. STENWIG, A.E., JAKOBSEN, K.S. and LOTHE, R.A. (2002). Frequent promoter hypermethylation of the O6-Methylguanine-DNAMethyltransferase (MGMT) gene in testicular cancer. Oncogene 21: 8878-8884.

SNEAD, N.M. and ROSSI, J.J. (2010). Biogenesis and function of endogenous and exogenous siRNAs. Wiley Interdiscip Rev RNA 1: 117-131.

SPERGER, J.M., CHEN, X., DRAPER, J.S., ANTOSIEWICZ, J.E., CHON, C.H., JONES, S.B., BROOKS, J.D., ANDREWS, P.W., BROWN, P.O. and THOMSON, J.A. (2003). Gene expression patterns in human embryonic stem cells and human pluripotent germ cell tumors. Proc Natl Acad Sci USA 100: 13350-13355.

STEVENS, L.C. (1962). Testicular teratomas in fetal mice. J Natl Cancer Inst 28 : 247-267

STEVENS, L.C. (1964). Experimental Production of Testicular Teratomas in Mice. Proc Natl Acad Sci USA 52: 654-661.

STEVENS, L.C. (1967). Origin of testicular teratomas from primordial germ cells in mice. J Natl Cancer Inst 38: 549-552.

STEVENS, L.C. (1973). Anew inbred subline of mice (129-terSv) with a high incidence of spontaneous congenital testicular teratomas. J Natl Cancer Inst 50: 235-242.

STEVENS, L.C. (1984). Spontaneous and experimentally induced testicular teratomas in mice. Cell Differ 15: 69-74.

STEVENS, L.C. and HUMMEL, K.P. (1957). A description of spontaneous congenital testicular teratomas in strain 129 mice. J Natl Cancer Inst 18: 719-747.

STEVENS, L.C. and LITTLE, C.C. (1954). Spontaneous Testicular Teratomas in an Inbred Strain of Mice. Proc Natl Acad Sci USA 40: 1080-1087.

STORGAARD, L., BONDE, J.P. and OLSEN, J. (2006). Male reproductive disorders in humans and prenatal indicators of estrogen exposure. A review of published epidemiological studies. Reprod Toxicol 21: 4-15.

STOUDER, C. and PAOLONI-GIACOBINO, A. (2010). Transgenerational effects of the endocrine disruptor vinclozolin on the methylation pattern of imprinted genes in the mouse sperm. Reproduction 139: 373-379.

STROHMEYER, T., REESE, D., PRESS, M., ACKERMANN, R., HARTMANN, M. and SLAMON, D. (1995). Expression of the c-kit proto-oncogene and its ligand stem cell factor (SCF) in normal and malignant human testicular tissue. J Urol 153: 511-515.

SURANI, M.A. and HAJKOVA, P. (2010). Epigenetic reprogramming of mouse germ cells toward totipotency. Cold Spring Harb Symp Quant Biol 75: 211-218.

SZABO, P.E. and MANN, J.R. (1995). Biallelic expression of imprinted genes in the mouse germ line: implications for erasure, establishment, and mechanisms of genomic imprinting. Genes Dev 9: 1857-1868.

TESSEL, M.A., KRETT, N.L. and ROSEN, S.T. (2010). Steroid receptor and microRNA regulation in cancer. Curr Opin Oncol 22: 592-597.

THOMAS, D. (2010). Gene--environment-wide association studies: emerging approaches. Nat Rev Genet 11: 259-272.

TILGHMAN, S.L., BRATTON, M.R., SEGAR, H.C., MARTIN, E.C., RHODES, L.V., LI, M., MCLACHLAN, J.A., WIESE, T.E., NEPHEW, K.P. and BUROW, M.E. (2012). Endocrine disruptor regulation of microRNA expression in breast carcinoma cells. PLoS One 7: e32754.

TOBI, E.W., LUMEY, L.H., TALENS, R.P., KREMER, D., PUTTER, H., STEIN, A.D. 
SLAGBOOM, P.E. and HEIJMANS, B.T. (2009). DNA methylation differences after exposure to prenatal famine are common and timing- and sex-specific. Hum Mol Genet 18: 4046-4053.

TOPPARI, J., LARSEN, J.C., CHRISTIANSEN, P., GIWERCMAN, A., GRANDJEAN, P., GUILLETTE, L.J., JR., JEGOU, B., JENSEN, T.K., JOUANNET, P., KEIDING, N. et al., (1996). Male reproductive health and environmental xenoestrogens. Environ Health Perspect 104 Suppl 4: 741-803.

USHIDA, H., KAWAKAMI, T., MINAMI, K., CHANO, T., OKABE, H., OKADA, Y. and OKAMOTO, K. (2012). Methylation profile of DNA repetitive elements in human testicular germ cell tumor. Mol Carcinog. 51: 711-722.

UZUMCU, M., SUZUKI, H. and SKINNER, M.K. (2004). Effect of the anti-androgenic endocrine disruptor vinclozolin on embryonic testis cord formation and postnatal testis development and function. Reprod Toxicol 18: 765-774.

VAN GURP, R.J., OOSTERHUIS, J.W., KALSCHEUER, V., MARIMAN, E.C. and LOOIJENGA, L.H. (1994). Biallelic expression of the H19 and IGF2 genes in human testicular germ cell tumors. J Natl Cancer Inst 86: 1070-1075.

VAN IJZENDOORN, M.H., BAKERMANS-KRANENBURG, M.J., BELSKY, J., BEACH, S., BRODY, G., DODGE, K.A., GREENBERG, M., POSNER, M. and SCOTT, S. (2011). Gene-by-environment experiments: a new approach to finding the missing heritability. Nat Rev Genet 12: 881; author reply 881.

VIDAEFF, A.C. and SEVER, L.E. (2005). In utero exposure to environmental estrogens and male reproductive health: a systematic review of biological and epidemiologic evidence. Reprod Toxicol 20: 5-20.

VINCENT, S.D., DUNN, N.R., SCIAMMAS, R., SHAPIRO-SHALEF, M., DAVIS, M.M., CALAME, K., BIKOFF, E.K. and ROBERTSON, E.J. (2005). The zinc finger transcriptional repressor Blimp1/Prdm1 is dispensable for early axis formation but is required for specification of primordial germ cells in the mouse. Development 132: 1315-1325.

VISWANATHAN, S.R. and DALEY, G.Q. (2010). Lin28: A microRNA regulator with a macro role. Cell 140: 445-449.

VISWANATHAN, S.R., DALEY, G.Q. and GREGORY, R.I. (2008). Selective blockade of microRNA processing by Lin28. Science 320: 97-100.

VON EYBEN, F.E. (2004). Chromosomes, genes, and development of testicular germ cell tumors. Cancer Genet Cytogenet 151: 93-138.

VOORHOEVE, P.M., LE SAGE, C., SCHRIER, M., GILLIS, A.J., STOOP, H., NAGEL, R., LIU, Y.P., VAN DUIJSE, J., DROST, J., GRIEKSPOOR, A. et al., (2007). A genetic screen implicates miRNA-372 and miRNA-373 as oncogenes in testicular germ cell tumors. Adv Exp Med Biol 604: 17-46.

WADDINGTON, C.H. (1942). The epigenotype. Endeavour 1: 18.

WANG, H., SARTINI, B.L., MILLETTE, C.F. and KILPATRICK, D.L. (2006). Adevelopmental switch in transcription factor isoforms during spermatogenesis controlled by alternative messenger RNA 3'-end formation. Biol Reprod 75: 318-323.

WANG, Y.C., CHEN, Y.L., YUAN, R.H., PAN, H.W., YANG, W.C., HSU, H.C. and JENG, Y.M. (2010). Lin-28B expression promotes transformation and invasion in human hepatocellular carcinoma. Carcinogenesis 31: 1516-1522.

WANG, Z., LUO, H., PAN, X., LIAO, M. and HOU, Y. (2012). A model for data analysis of microRNA expression in forensic body fluid identification. Forensic Sci Int Genet 6: 419-423.

WEBER, M., HELLMANN, I., STADLER, M.B., RAMOS, L., PAABO, S., REBHAN, M. and SCHUBELER, D. (2007). Distribution, silencing potential and evolutionary impact of promoter DNAmethylation in the human genome. Nat Genet39:457-466.

WEIDINGER, G., STEBLER, J., SLANCHEV, K., DUMSTREI, K., WISE, C., LOVELLBADGE, R., THISSE, C., THISSE, B. and RAZ, E. (2003). dead end, a novel vertebrate germ plasm component, is required for zebrafish primordial germ cell migration and survival. Curr Biol 13: 1429-1434.
WEST, J.A., VISWANATHAN, S.R., YABUUCHI, A., CUNNIFF, K., TAKEUCHI, A., PARK, I.H., SERO, J.E., ZHU, H., PEREZ-ATAYDE, A., FRAZIER, A.L. et al., (2009). A role for Lin28 in primordial germ-cell development and germ-cell malignancy. Nature 460: 909-913.

WESTERN, P. (2009). Foetal germ cells: striking the balance between pluripotency and differentiation. Int J Dev Biol 53: 393-409.

WESTERN, P.S., MILES, D.C., VAN DEN BERGEN, J.A., BURTON, M. and SINCLAIR, A.H. (2008). Dynamic regulation of mitotic arrest in fetal male germ cells. Stem Cells 26: 339-347.

WOHLFAHRT-VEJE, C., MAIN, K.M. and SKAKKEBAEK, N.E. (2009). Testicular dysgenesis syndrome: foetal origin of adult reproductive problems. Clin Endocrinol (Oxf) 71: 459-465

WOODRUFF, T.J., CARLSON, A., SCHWARTZ, J.M. and GIUDICE, L.C. (2008). Proceedings of the Summit on Environmental Challenges to Reproductive Health and Fertility: executive summary. Fertil Steril 89: 281-300.

WU, S., ZHU, J., LI, Y., LIN, T., GAN, L., YUAN, X., XIONG, J., LIU, X., XU, M., ZHAO, D. et al., (2010). Dynamic epigenetic changes involved in testicular toxicity induced by di-2-(ethylhexyl) phthalate in mice. Basic Clin Pharmacol Toxicol 106: 118-23.

WYLIE, C.C. (1993). The biology of primordial germ cells. Eur Urol 23: 62-66; discussion 67.

YAMAGATA, K., FUJIYAMA, S., ITO, S., UEDA, T., MURATA, T., NAITOU, M., TAKEYAMA, K., MINAMI, Y., O'MALLEY, B.W. and KATO, S. (2009). Maturation of microRNA is hormonally regulated by a nuclear receptor. Mol Cell 36: 340-7.

YAMASAKI, S. and ANDERSON, P. (2008). Reprogramming mRNA translation during stress. Curr Opin Cell Biol 20: 222-226.

YAO, P.L., LIN, Y.C. and RICHBURG, J.H. (2012). Mono-(2-ethylhexyl) phthalate (MEHP) promotes invasion and migration of human testicular embryonal carcinoma cells. Biol Reprod 86: 160.

YEO, G., HOLSTE, D., KREIMAN, G. and BURGE, C.B. (2004). Variation in alternative splicing across human tissues. Genome Biol 5: R74.

YEOM, Y.I., FUHRMANN, G., OVITT, C.E., BREHM, A., OHBO, K., GROSS, M., HUBNER, K. and SCHOLER, H.R. (1996). Germline regulatory element of Oct-4 specific for the totipotent cycle of embryonal cells. Development 122: 881-894.

YOUNGREN, K.K., COVENEY, D., PENG, X., BHATTACHARYA, C., SCHMIDT, L.S., NICKERSON, M.L., LAMB, B.T., DENG, J.M., BEHRINGER, R.R., CAPEL, B. et al., (2005). The Ter mutation in the dead end gene causes germ cell loss and testicular germ cell tumours. Nature 435: 360-364.

YOUNGSON, N.A. and WHITELAW, E. (2008). Transgenerational epigenetic effects. Annu Rev Genomics Hum Genet 9: 233-257.

YU, Z., RAABE, T. and HECHT, N.B. (2005). MicroRNA Mirn122a reduces expression of the posttranscriptionally regulated germ cell transition protein 2 (Tnp2) messenger RNA (mRNA) by mRNA cleavage. Biol Reprod 73: 427-33.

ZAFARANA, G., GRYGALEWICZ, B., GILLIS, A.J., VISSERS, L.E., VAN DE VLIET, W., VAN GURP, R.J., STOOP, H., DEBIEC-RYCHTER, M., OOSTERHUIS, J.W., VAN KESSEL, A.G. etal., (2003). 12p-amplicon structure analysis in testicular germ cell tumors of adolescents and adults by array CGH. Oncogene 22: 7695-701.

ZHANG, B., PAN, X., COBB, G.P. and ANDERSON, T.A. (2007). microRNAs as oncogenes and tumor suppressors. Dev Biol 302: 1-12.

ZHANG, J., ZHAO, H., GAO, Y. and ZHANG, W. (2012). Secretory miRNAs as novel cancer biomarkers. Biochim Biophys Acta 1826: 32-43.

ZHANG, W. and DOLAN, M.E. (2010). The emerging role of microRNAs in drug responses. Curr Opin Mol Ther 12: 695-702.

ZHANG, X. and HO, S.M. (2011). Epigenetics meets endocrinology. J Mol Endocrinol 46: R11-32. 


\section{Further Related Reading, published previously in the Int. J. Dev. Biol.}

Germline stem cells and sex determination in Hydra

Chiemi Nishimiya-Fujisawa and Satoru Kobayashi

Int. J. Dev. Biol. (2012) 56: 499-508

Impaired meiotic competence in putative primordial germ cells produced from mouse embryonic stem cells

Marianna Tedesco, Donatella Farini and Massimo De Felic

Int. J. Dev. Biol. (2011) 55: 215-222

In vitro germ cell differentiation during sex differentiation in a teleost fish Tohru Kobayashi

Int. J. Dev. Biol. (2010) 54: 105-111

Differentiation of mouse primordial germ cells into female or male germ cells

N Nakatsuji and S Chuma

Int. J. Dev. Biol. (2001) 45: 541-548

The meiotic specific synaptonemal complex protein SCP3 is expressed by female and male primordial germ cells of the mouse embryo

A D Di Carlo, G Travia and M De Felici

Int. J. Dev. Biol. (2000) 44: 241-244
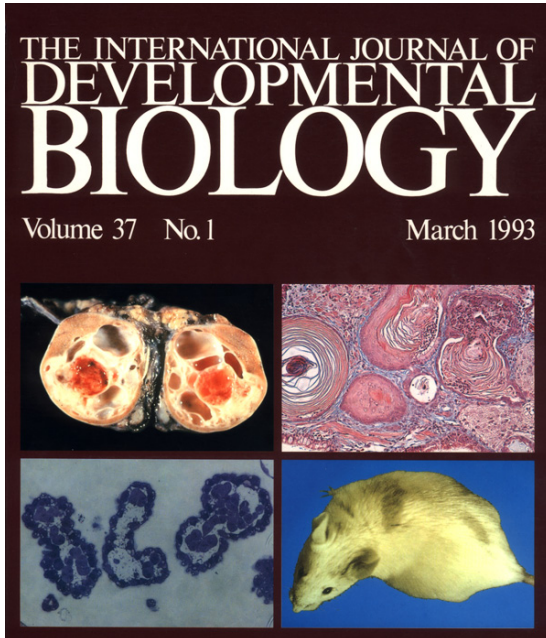

Developmental Aspects of Neoplasia
5 yr ISI Impact Factor $(2011)=2.959$

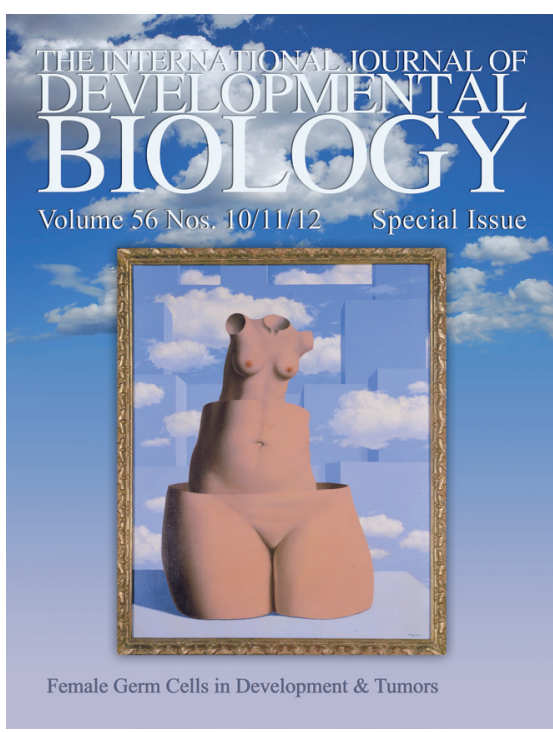

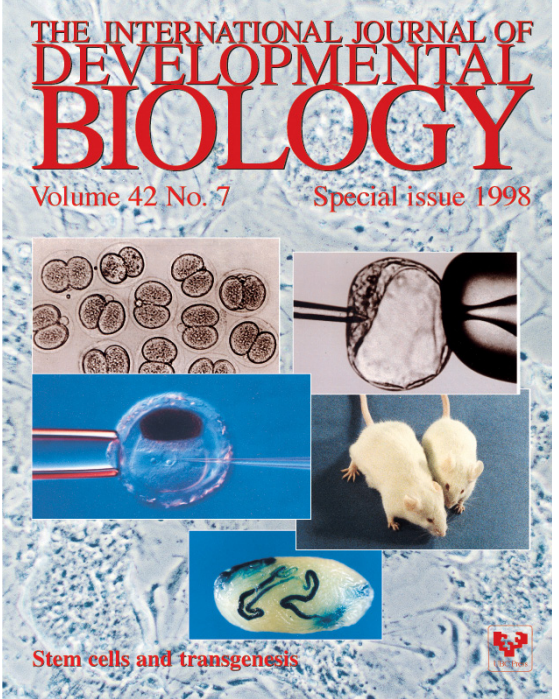

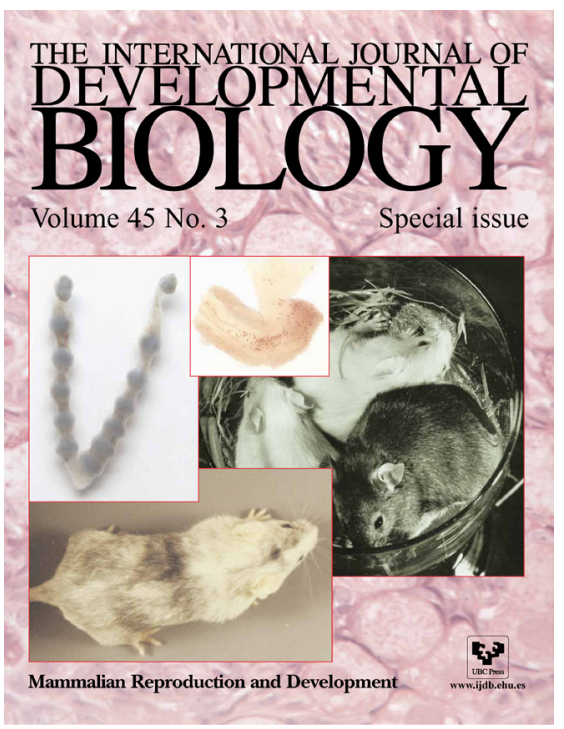

